\title{
Development of Small-Molecule MERS-CoV Inhibitors
}

\author{
Ruiying Liang ${ }^{1,+}{ }^{\dagger}$, Lili Wang ${ }^{2,+}$, Naru Zhang ${ }^{3,+}$, Xiaoqian Deng ${ }^{1}$, Meng Su ${ }^{1}$, Yudan Su ${ }^{1}$, \\ Lanfang $\mathrm{Hu}^{1}$, Chen $\mathrm{He}^{1}$, Tianlei Ying ${ }^{4, *}$, Shibo Jiang ${ }^{4, *}$ and Fei $\mathrm{Yu}^{1, * \mathbb{D}}$ \\ 1 College of Life and Science, Hebei Agricultural University, Baoding 071001, China; \\ ruiyingliang@outlook.com (R.L.); dengxiaoqian0926@hotmail.com (X.D.); sumeng123@hotmail.com (M.S.); \\ suyudan123@hotmail.com (Y.S.); hlf0519@hotmail.com (L.H.); hechen285@hotmail.com (C.H.) \\ 2 Research Center of Chinese Jujube, Hebei Agricultural University, Baoding 071001, China; \\ yywll@hebau.edu.cn \\ 3 Department of Clinical Medicine, Faculty of Medicine, Zhejiang University City College, Hangzhou 310015, \\ China; zhangnr@zucc.edu.cn \\ 4 Key Laboratory of Medical Molecular Virology of MOE/MOH, School of Basic Medical Sciences, \\ Fudan University, Shanghai 200032, China \\ * Correspondence: shmyf@hebau.edu.cn (F.Y.); shibojiang@fudan.edu.cn (S.J.); tlying@fudan.edu.cn (T.Y.); \\ Tel.: +86-312-7528935 (F.Y.); +86-21-54237673 (S.J.); +86-21-54237761 (T.Y.) \\ + These authors contributed equally to this work.
}

Received: 24 November 2018; Accepted: 12 December 2018; Published: 17 December 2018

\begin{abstract}
Middle East respiratory syndrome coronavirus (MERS-CoV) with potential to cause global pandemics remains a threat to the public health, security, and economy. In this review, we focus on advances in the research and development of small-molecule MERS-CoV inhibitors targeting different stages of the MERS-CoV life cycle, aiming to prevent or treat MERS-CoV infection.
\end{abstract}

Keywords: MERS-CoV; mechanism of action; small-molecule inhibitor

\section{Introduction}

Middle East respiratory syndrome coronavirus (MERS-CoV) has posed a serious threat to public health worldwide because it can cause severe respiratory disease in humans with high mortality (about 36\%) [1]. As of 27 November 2018, a total of 2266 human MERS-CoV infections with 804 deaths had been reported from 27 countries in the Middle East, North Africa, Europe, Asia, and North America to the World Health Organization (WHO), with 83\% reported by the Kingdom of Saudi Arabia (Figure 1) (https:/ / www.who.int/emergencies/mers-cov/en/).

Phylogenetic and sequencing data strongly suggest that MERS-CoV belongs to the C-lineage of the genus betacoronavirus, the first known lineage $C$ betacoronavirus associated with human infections [2]. The clinical features of MERS-CoV infection range from asymptomatic infection to rapidly progressive acute hypoxemic respiratory failure and extrapulmonary organ dysfunction [3-5]. At present, no effective vaccine or therapeutics are available for the prevention or treatment of MERS-CoV infection [6-8]. However, many basic and clinical studies on anti-MERS-CoV agents have been completed or are ongoing. In this review, we focus on current progress in the research and development of small-molecule MERS-CoV inhibitors, either peptides or compounds, targeting different stages of the MERS-CoV life cycle, aiming to prevent or treat MERS-CoV infection. 


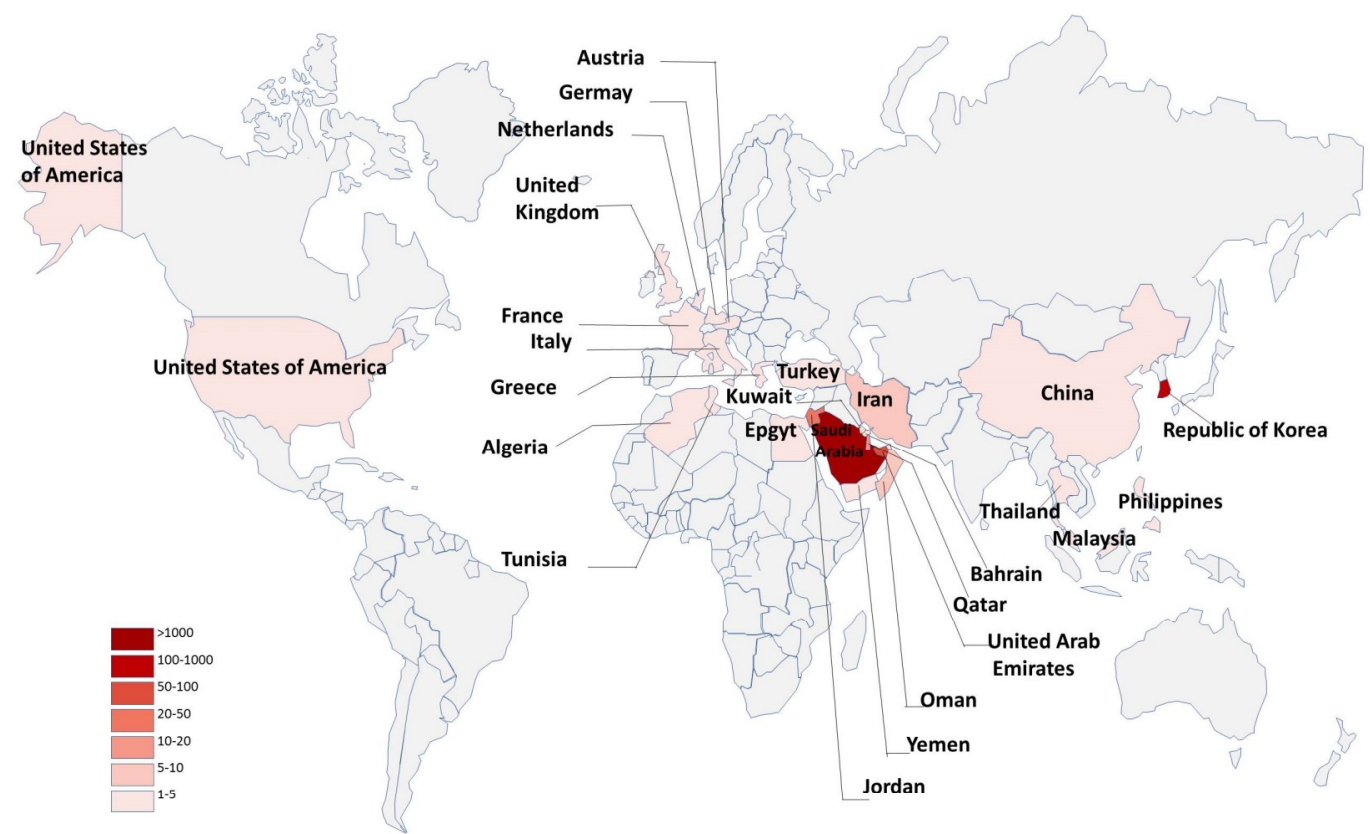

Figure 1. Summary of morbidity statistics with country- and quarter-level panel data.

\section{MERS-CoV Life Cycle and Potential Targets for the Development of Small-Molecule Inhibitors Against MERS-CoV Infection}

MERS-CoV enters host cells through two pathways. The first involves plasma membrane fusion, which relies on spike (S) protein activation by secreted or surface proteases, such as the transmembrane protease serine 2 (TMPRSS2) and the human airway trypsin-like protease (HAT). The second involves endosomal membrane fusion, in which spike protein activation is facilitated by the $\mathrm{pH}$-dependent endosomal protease cathepsin L (CTSL) $[9,10]$. The spike protein plays a key role in MERS-CoV attachment to host cells and virus-cell membrane fusion [11]. It contains 1353 amino acids within the viral envelope in trimeric state [12]. Spike protein consists of S1 and S2 subunits. The $\mathrm{S} 1$ subunit contains the receptor binding domain (RBD), while the S2 subunit contains the fusion peptide (FP), a long heptad repeat 1 domain (HR1) and a short heptad repeat 2 domain (HR2) $[13,14]$. MERS-CoV enters the host cell by binding the viral particle via the RBD in spike protein to the cellular receptor dipeptidyl peptidase-4 (DPP4) on the surface of the host cell [12,15]. Then, S2 changes its conformation and inserts its FP into the plasma membrane, or the endosomal membrane if the virion is in the endosome. The HR2 binds to the HR1 to form a six-helix bundle (6-HB) fusion core, which brings viral and cell membranes into close apposition for fusion $[14,16,17]$. During this process, RBD, DPP4, HR1, HR2, and the related proteases, e.g., HAT and TMPRSS2, can all serve as targets for the development of MERS-CoV fusion/entry inhibitors.

After MERS-CoV entry into the host's cells, the positive RNA genome is translated in the cytoplasm. The genome can be translated into two polyproteins: ppla and pplb, which are cleaved into 16 nonstructural proteins by $\mathrm{PL}_{\text {pro }}$ (papain-like protease) and $3 \mathrm{CL}_{\text {pro }}$ (3-chymotrypsin-like protease). Hence, the proteases that are critically important for MERS-CoV replication can also be considered as targets for developing MERS-CoV replication inhibitors. However, information about the enzymes required for producing more genome copies and subgenomic mRNA for virus replication is limited. Then, the RNA genome and structural proteins are packaged into viral particles in host cells, and the progeny virus particles are finally released from host cells (Figure 2). Although these steps can also be used as targets for the development of MERS-CoV maturation-and-release inhibitors, no such inhibitors have been reported so far. 


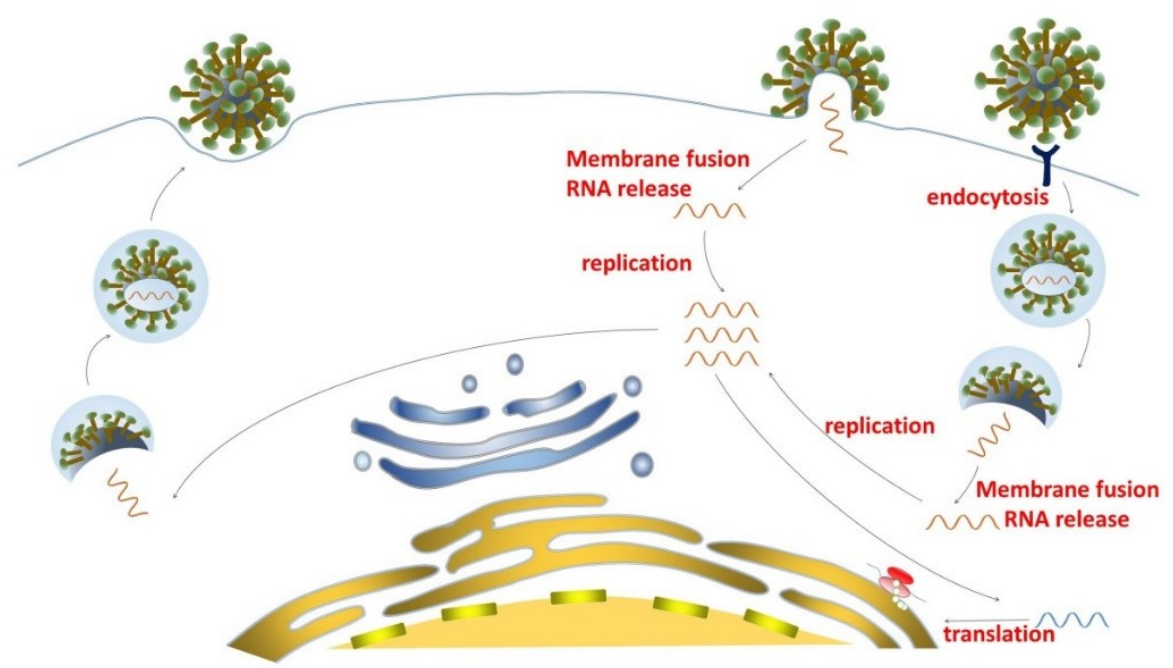

Figure 2. Schematic diagram of Middle East respiratory syndrome coronavirus (MERS-CoV) infection. MERS-CoV enters host cells by plasma membrane fusion (membrane fusion) or endosomal membrane fusion (endocytosis), and then releases the viral RNA into the cytoplasm. The RNA genome is replicated and viral proteins are produced. The progeny virus is generated and released from the infected cells.

\section{Current Small-Molecule Inhibitors Against MERS-CoV Infection and Their Mechanisms of Action}

\subsection{MERS-CoV Entry Inhibitors}

MERS-CoV S protein plays a key role in mediating virus entry into host target cells. This process includes binding to host receptors, viral fusion, and final entry into host cells. MERS-CoV pseudovirus expressing $\mathrm{S}$ protein, which allows for single-cycle infection in cells expressing receptor DPP4, can be used for screening MERS-CoV fusion/entry inhibitors.

HR2P, spanning residues 1251-1286 in the HR2 domain, with low or no toxic effect in vitro, can effectively inhibit MERS-CoV replication by interacting with the HR1 domain to block spike protein-mediated cell-cell fusion and MERS-CoV pseudovirus entry (Table 1; Figure 3) [16]. To increase its stability, solubility, and anti-MERS-CoV activity, Lu et al. introduced a Glu, Lys, or Arg residue into HR2P, generating a new peptide, HR2P-M2 (Table 1). HR2P-M2 was indeed found to be more stable and soluble than HR2P. It blocked fusion core formation between HR1 and HR2 peptides by binding to the viral S protein HR1 domain and inhibiting $S$ protein-mediated membrane fusion with an $\mathrm{EC}_{50}$ of $0.55 \mu \mathrm{M}$ (Figure 4) [16,23]. HR2P-M2 is highly effective in inhibiting MERS-CoV infection in both Calu-3 and Vero cells with an $\mathrm{EC}_{50}$ of about $0.6 \mu \mathrm{M}$. Intranasal application of HR2P-M2 could significantly reduce the titers of MERS-CoV in the lung of Ad5-hDPP4 (adenovirus serotype-5-human dipeptidyl peptidase 4)-transduced mice [16,18]. Furthermore, intranasal administration of HR2P-M2 before viral challenge fully protected hDPP4-transgenic mice from MERS-CoV infection, whereas all untreated mice died 8 days after viral challenge [24]. Furthermore, by combining HR2P-M2 with interferon $\beta$, protection was enhanced for Ad5-hDPP4-transduced mice against infection by MERS-CoV strains with or without mutations in the HR1 region of the $S$ protein, with $>1000$-fold reduction of viral titers in lung [18]. 
Table 1. Peptide viral inhibitors against MERS-CoV.

\begin{tabular}{|c|c|c|c|c|c|c|}
\hline Compound & Sequence & Testing Model & Cell Lines Tested & $\mathrm{EC}_{50}(\mu \mathrm{M})$ & $\mathrm{CC}_{50}(\mu \mathrm{M})$ & Ref. \\
\hline \multicolumn{7}{|c|}{ Peptide inhibitors disturbing membrane fusion } \\
\hline HR2P & SLTQINTTLLDLTYEMLSLQQVVKALNESYIDLKEL & In vitro & $\begin{array}{l}\text { Vero cells } \\
\text { Huh-7 cells }\end{array}$ & $\begin{array}{c}0.6 \\
0.93 \pm 0.15^{b}\end{array}$ & $>1000$ & [16] \\
\hline HR2P-M2 & SLTQINTTLLDLEYEMKKLEEVVKKLEESYIDLKEL & $\begin{array}{l}\text { In vitro; in vivo: } \\
\text { hDPP4 Tg mice }\end{array}$ & $\begin{array}{l}\text { Calu-3 and Vero cells; } \\
\text { Ad5-hDPP4 mice }\end{array}$ & $0.55 \pm 0.04^{b}$ & - & $\begin{array}{c}{[16,18,} \\
19]\end{array}$ \\
\hline P21S10 & LDLTYEM LSLQQVV K*LNE*Y & In vitro & Huh-7 cells & $0.97 \pm 0.08 ; 0.33 \pm 0.04^{b}$ & $>100$ & [20] \\
\hline P21S2 & L*LTY*M LSLQQVV KALNESY & In vitro & Huh-7 cells & $3.90 \pm 1.1^{\mathrm{b}}$ & - & [20] \\
\hline P21S4 & LDLT*EM L*LQQVV KALNESY & In vitro & Huh-7 cells & $7.14 \pm 0.7^{b}$ & - & [20] \\
\hline P21S5 & LDLTYEM *SLQ*VV KALNESY & In vitro & Huh-7 cells & $10.7 \pm 2.6^{\mathrm{b}}$ & - & [20] \\
\hline P21S8 & LDLTYEM LSLQ*VV K*LNESY & In vitro & Huh-7 cells & $\begin{array}{r}3.03 \pm 0.29 \\
0.26 \pm 0.05 b\end{array}$ & $>100$ & [20] \\
\hline P21S9 & LDLTYEM LSLQQVV *ALN*SY & In vitro & Huh-7 cells & $14.1 \pm 2.3^{b}$ & - & [20] \\
\hline P21L2 & LXLTYXM LSLQQVV KALNESY & In vitro & Huh-7 cells & $10.9 \pm 1.1^{\mathrm{b}}$ & - & [20] \\
\hline P21L4 & LDLTXEM LXLQQVV KALNESY & In vitro & Huh-7 cells & $8.21 \pm 0.9^{b}$ & - & [20] \\
\hline P21L5 & LDLTYEM XSLQXVV KALNESY & In vitro & Huh-7 cells & $4.49 \pm 0.6^{\mathrm{b}}$ & - & [20] \\
\hline P21L8 & LDLTYEM LSLQXVV KXLNESY & In vitro & Huh-7 cells & $20.6 \pm 3.3^{b}$ & - & [20] \\
\hline P21L9 & LDLTYEM LSLQQVV XALNXSY & In vitro & Huh-7 cells & $10.9 \pm 1.0^{\mathrm{b}}$ & - & [20] \\
\hline P21L10 & LDLTYEM LSLQQVVV KXLNEXY & In vitro & Huh-7 cells & $3.55 \pm 0.2^{b}$ & - & [20] \\
\hline P21R8 & LDLTYEM LSLQ^VV K^LNESY & In vitro & Huh-7 cells & $16.3 \pm 1.1^{\mathrm{b}}$ & - & [20] \\
\hline P21S8Z & LDLTYEZ LSLQ*VV K*LNESY & In vitro & Huh-7 cells & $\begin{array}{r}2.80 \pm 0.74 \\
0.63 \pm 0.05^{b}\end{array}$ & $>100$ & [20] \\
\hline P21S8F & LDLTYEM LSLQ*VV K*LNESF & In vitro & Huh-7 cells & $2.16 \pm 1.1^{\mathrm{b}}$ & - & [20] \\
\hline P21S8ZF & LDLTYES LSLQ*VV K*LNESF & In vitro & Huh-7 cells & $3.89 \pm 0.8^{\mathrm{b}}$ & - & [20] \\
\hline 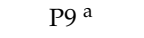 & NGAICWGPCPTAFRQIGNCGHFKVRCCKIR & In vitro & MDCK cells & $5.00 \mu \mathrm{g} / \mathrm{mL}$ & $380 \mu \mathrm{g} / \mathrm{mL}$ & [21] \\
\hline LLS & LEELSKKLEELSKKLEELSKKLEELSKKLEELSKK- $\beta$ A-K (C16) & In vitro & Huh-7 cells & $0.24 \pm 0.08^{b}$ & $4.04 \pm 0.4$ & [22] \\
\hline IIS & IEEISKKIEEISKKIEEISKKIEEISKKIEEISKK- $\beta$ A-K (C16) & In vitro & Huh-7 cells & $0.10 \pm 0.02^{\mathrm{b}}$ & $88.8 \pm 28$ & [22] \\
\hline AAS & AEEASKKAEEASKKAEEASKKAEEASKKAEEASKK-ßA-K(C16) & In vitro & Huh-7 cells & $4.47 \pm 1.7^{\mathrm{b}}$ & $2.38 \pm 0.9$ & [22] \\
\hline FFS & 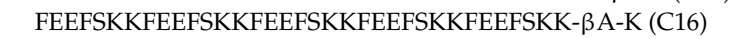 & In vitro & Huh-7 cells & $3.11 \pm 0.9^{b}$ & $>100$ & [22] \\
\hline YYS & YEEYSKKYEEYSKKYEEYSKKYEEYSKKYEEYSKK- $\beta A-K(C 16)$ & In vitro & Huh-7 cells & $6.26 \pm 2.1^{b}$ & $19.8 \pm 1.6$ & [22] \\
\hline IIY & 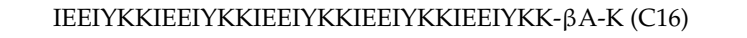 & In vitro & Huh-7 cells & $0.52 \pm 0.4^{b}$ & $>100$ & [22] \\
\hline IIW & IEEIWKKIEEIWKKIEEIWKKIEEIWKKIEEIWKK- $\beta$ A-K (C16) & In vitro & Huh-7 cells & $10.6 \pm 2.4^{\mathrm{b}}$ & $>100$ & [22] \\
\hline $\mathrm{IIH}$ & IEEIHKKIEEIHKKIEEIHKKIEEIHKKIEEIHKK- $\beta$ A-K (C16) & In vitro & Huh-7 cells & $1.68 \pm 0.47^{b}$ & $>100$ & [22] \\
\hline IIQ & IEEIQKKIEEIQKKIEEIQKKIEEIQKKIEEIQKK-ßA-K (C16) & In vitro & Huh-7 cells & $\begin{array}{r}0.13 \pm 0.1 \\
0.11 \pm 0.02^{b}\end{array}$ & $>100$ & [22] \\
\hline IIK & 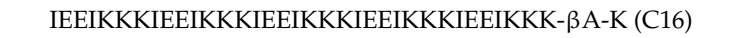 & In vitro & Huh-7 cells & $0.45 \pm 0.13^{b}$ & $4.54 \pm 0.6$ & [22] \\
\hline IIE & IEEIEKKIEEIEKKIEEIEKKIEEIEKKIEEIEKK- $\beta$ A-K (C16) & In vitro & Huh-7 cells & $2.93 \pm 0.95^{b}$ & $>100$ & [22] \\
\hline
\end{tabular}

a P9-aci-1: three acidic amino acids D, E, and D were added to the C-terminus of P9. ${ }^{\mathrm{b}}$ Concentration of peptide that blocks MERS-CoV S-mediated cell-cell fusion. " - " indicates data not available. " "* indicates the position of the $\mathrm{S} 5$ residues, which react to form the all hydrocarbon staple. "^" indicates the positions of the $\mathrm{R} 5$ amino acids, which react to form staples. $\mathrm{EC}$ 50: concentration for $50 \%$ of maximal effect. $\mathrm{CC}_{50}$ : the $50 \%$ cytotoxicity concentrations. 


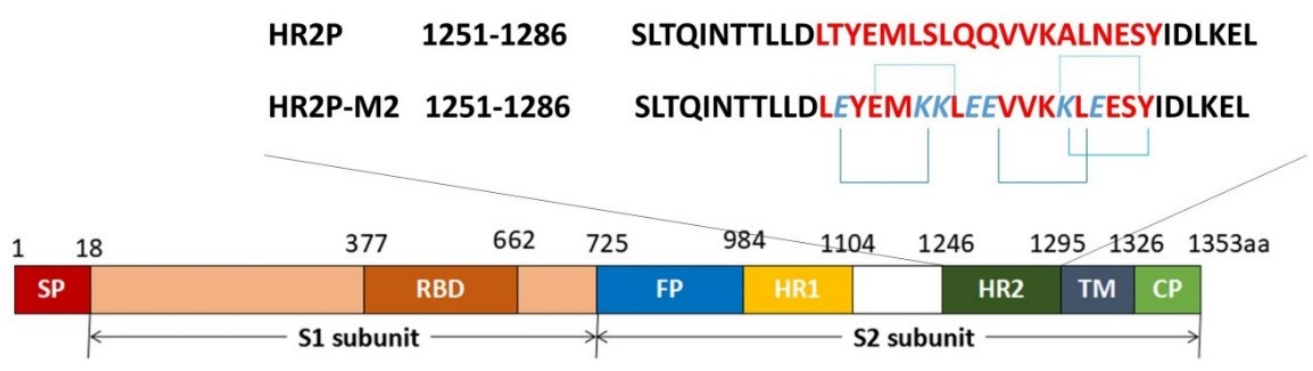

Figure 3. Schematic representation of MERS-CoV S (spike) protein S1 subunit and S2 subunit. RBD, receptor binding domain; FP, fusion peptide; HR1, heptad repeat 1 domain; HR2, heptad repeat 2 domain; TM, transmembrane domain; $\mathrm{CP}$, cytoplasmic domain. The residue numbers of each region correspond to their positions in the $S$ protein of MERS-CoV. HR2P, the peptide derived from the HR2 domain of MERS-CoV S protein S2 subunit; HR2P-M2, HR2P analogous peptide with mutations.

DPP4 binding with RBD

A

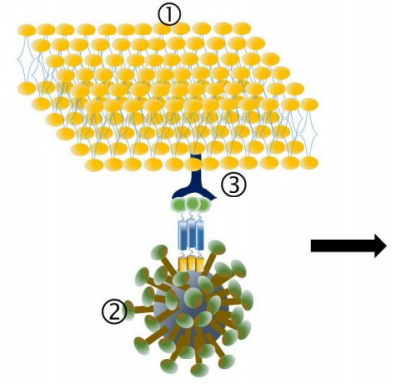

(1)

B

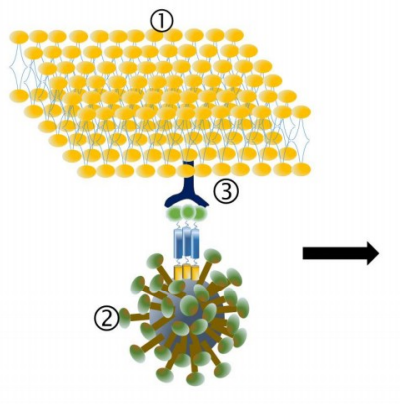

Internediate (prehairpin)

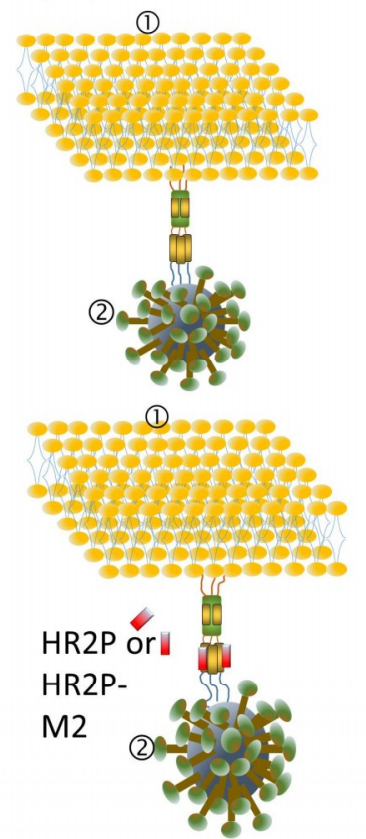

Fusion (hairpin)
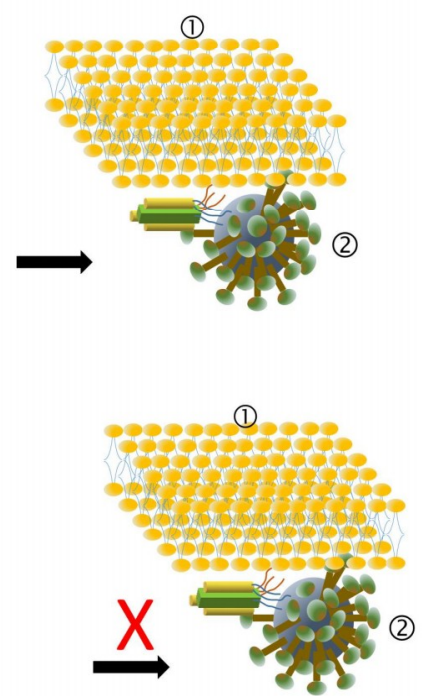

Figure 4. Schematic representation of the inhibition mechanism of HR2P and HR2P-M2. (1) Target cell membrane; (2) MERS-CoV; (3) dipeptidyl peptidase-4 (DPP4). (A) Mechanism of normal binding between a host cell and MERS-CoV. MERS-CoV enters the host cell by binding the viral particle via the RBD in spike protein to the cellular receptorDPP4 on the surface of the host cell. The HR2 binds to the HR1 to form a six-helix bundle (6-HB) fusion core, which brings viral and cell membranes into close apposition for fusion. (B) HR2P and HR2P-M2 block six-bundle fusion core formation between HR1 and HR2 peptides by binding to the viral S protein HR1 domain.

P21S10, the most effective fusion inhibitor of MERS-CoV, can inhibit MERS-CoV pseudovirus infection with an $\mathrm{EC}_{50}$ of about $1 \mu \mathrm{M}$ in Huh-7 cells and a $\mathrm{CC}_{50}$ of $>100 \mu \mathrm{M}$ in Huh-7 cells by CCK 8 (Cell Counting Kit-8) assay (Table 1) [20]. In addition, a series of synthesized stapled peptides, such as P21S10, P21S2, P21S4, P21S5, P21S8, P21S9, P21S8F, P21S8ZF, etc., could effectively inhibit infection by MERS-CoV pseudovirus and its spike protein-mediated cell fusion by blocking helix-mediated NHR (N-terminal heptad repeats) / CHR (C-terminal heptad repeats) interactions with a low $\mathrm{EC}_{50}$ and a high $\mathrm{CC}_{50}$ in Huh-7 cells [20].

P9, a short peptide, exhibited potent and broad spectrum antiviral effects against multiple respiratory viruses in vitro and in vivo [21,25]. P9 inhibited MERS-CoV with an $\mathrm{EC}_{50}$ of about $5 \mu \mathrm{g} / \mathrm{mL}$ 
in Madin-Darby canine kidney (MDCK) cells, obtained by plaque assay, and a $\mathrm{CC}_{50}$ of $380 \mu \mathrm{g} / \mathrm{mL}$ in MDCK cells obtained by MTT (3-(4,5-dimethyl-2-thiazolyl)-2,5-diphenyl-2-H-tetrazolium bromide) assay (Table 1) [21].

Lipopeptides are bioactive peptides that replicate the $\alpha$-helical chain from the viral fusion machinery [22]. All 12 lipopeptides inhibit cell-cell fusion mediated by MERS-CoV S protein with $\mathrm{EC}_{50}$ values ranging from 0.1 to $>10.0 \mu \mathrm{M}$ in Huh-7 cells (Table 1) [22]. Among these lipopeptides, LLS and IIS were found to be the most potent MERS-CoV fusion inhibitors with $\mathrm{EC}_{50}$ values of $0.24 \mu \mathrm{M}$ and $0.1 \mu \mathrm{M}$, respectively [22]. Other lipopeptides such as AAS, FFS, YYS, IIY, IIW, IIH, IIQ, IIK, and IIE can also inhibit cell-cell fusion mediated by MERS-CoV S protein with variable $\mathrm{EC}_{50}$ values [22].

Three neurotransmitter inhibitors, including chlorpromazine, fluphenazine, and promethazine, were moderate inhibitors of cell-cell fusion with $\mathrm{EC}_{50}$ values of about 23,15 , and $17 \mu \mathrm{M}$, respectively (Table 2; Figure 5(5), (45), (46)) [26]. They can also disrupt clathrin-mediated endocytosis to inhibit MERS-CoV [26].

A small-molecule HIV entry inhibitor targeting gp41 ADS-J1 (Figure 5(1)) at the concentration of $20 \mu \mathrm{M}$ could inhibit $>90 \%$ of MERS-CoV pseudovirus infection in NBL-7 and Huh-7 cells. ADS-J1 could interrupt the interactions between the HR1 and HR2 of MERS-CoV to form the six-helix bundle, thus inhibiting the entry of pseudotyped MERS-CoV with an $\mathrm{EC}_{50}$ of $0.6 \mu \mathrm{M}$ in the DPP4-expressing cell line and with a $\mathrm{CC}_{50}$ of $26.9 \mu \mathrm{M}$ in NBL-7 and Huh-7 cells by MTT assay (Table 2) [27].

The elucidation of MERS-CoV interaction with its host cell is critical to the development of antiviral interventions. In order to gain entry into host cells, MERS-CoV not only uses DPP4 as a functional virus receptor, but also utilizes certain cellular proteases, such as TMPRSS2 and members of the cathepsin family, as activators of the S glycoprotein [9]. TMPRSS2 is expressed in epithelial cells of the human respiratory and gastrointestinal tracts [28-31]. The respective enzymes from host cells are also excellent targets for the identification of small-molecule MERS-CoV inhibitors. The serine protease inhibitor camostat mesylate (camostat) could completely block syncytium formation, but only partially block virus entry into TMPRSS2-expressing Vero cells (Figure 5(2)) [31].

K11777, a compound known to inhibit cruzain, a cathepsin-like protease from the protozoan parasite Trypanosoma cruzi, can inhibit MERS-CoV with an EC 50 of $46 \mathrm{nM}$ (Figure 5(3)) [32,33].

Chloroquine inhibited MERS-CoV replication and blocked infection at an early step with an $\mathrm{EC}_{50}$ of $3 \mu \mathrm{M}$ and a $\mathrm{CC}_{50}$ of $58 \mu \mathrm{M}$ (Table 2; Figure 5(4)) [34]. Chlorpromazine inhibited MERS-CoV replication at both early and post-entry stages with an $\mathrm{EC}_{50}$ of about $5 \mu \mathrm{M}$ and a $\mathrm{CC}_{50}$ of $21 \mu \mathrm{M}$ (Table 2; Figure 5(5)) [34]. However, high cytotoxicity narrowed the therapeutic window in both monocyte-derived macrophages (MDMs) and dendritic cells (MDDCs) [34].

Ouabain and bufalin can inhibit MERS-CoV entry by blocking clathrin-mediated endocytosis (Figure 5(6), (7)) [25,35]. The addition of small amounts of ouabain $(50 \mathrm{nM})$ or bufalin (10 to $15 \mathrm{nM})$ inhibited infection with MERS-CoV and VSV (vesicular stomatitis virus) (Table 2), but only when the drug was added prior to inoculation in Huh-7 cells [35].

Dihydrotanshinone, a lipophilic compound, showed a decimal reduction at $0.5 \mu \mathrm{g} / \mathrm{mL}$ and excellent antiviral effects at $\geq 2 \mu \mathrm{g} / \mathrm{mL}$ with a reduction in titer from $6.5 \mathrm{Log}$ to $1.8 \mathrm{Log} \mathrm{TCID}_{50} / \mathrm{mL}$ by using a pseudovirus expressing MERS-CoV spike protein (Figure 5(8)) [36].

During the biosynthesis of MERS-CoV $S$ protein, the furin inhibitor decanoyl-RVKR-chloromethylketone (dec-RVKR-CMK) at $75 \mu \mathrm{M}$ can lead to a decrease of the 85-kDa cleaved product in MERS-CoV S wt and S2' mutant (Figure 5(9)) [37]. 


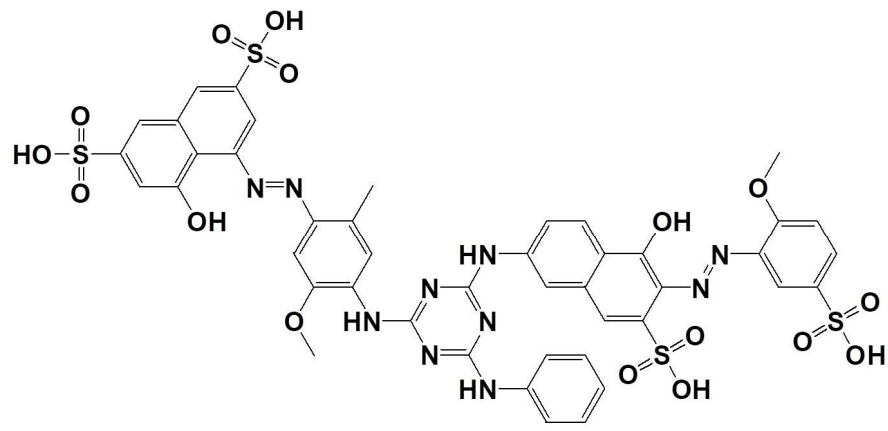

(1) ADS-J1

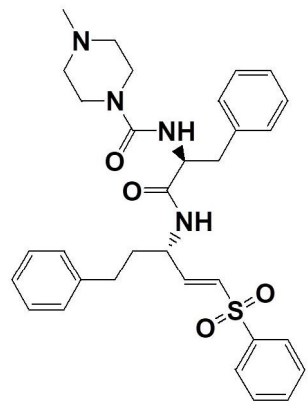

(3) K11777

(4) Chloroquine

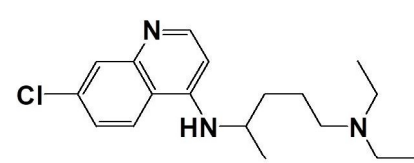<smiles>C[C@]12CC[C@@H](O)C[C@H]1CC[C@@H]1[C@@H]2CC[C@]2(C)[C@@H](c3ccc(=O)oc3)CC[C@]12O</smiles>

(7) Bufalin

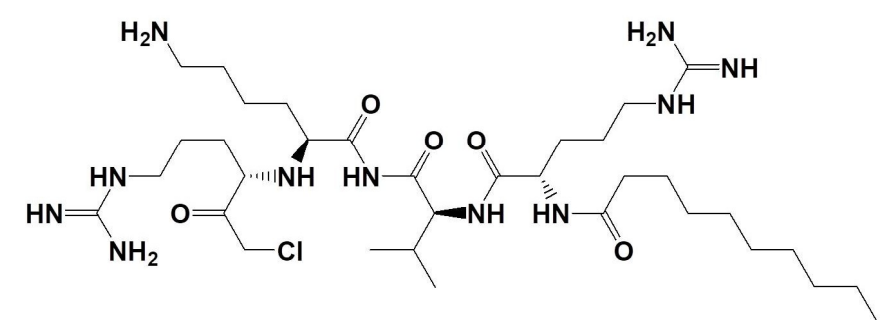

(9) Decanoyl-RVKR-chloromethylketone
(6) Ouabain<smiles>CN(C)C1COC(Cc2ccc(OC(=O)c3ccc(NC(=N)N)cc3)cc2)OC1</smiles>

(2) Camostat

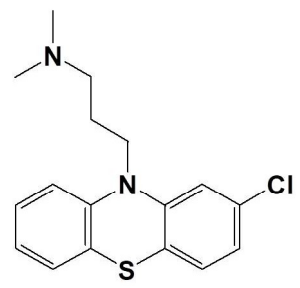

(5) Chlorpromazine

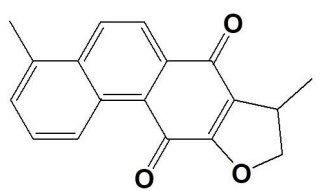

(8) Dihydrotanshinone 


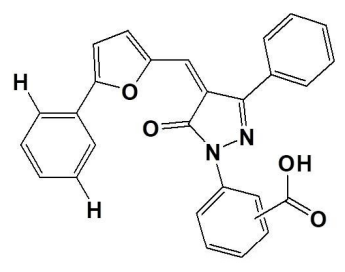

(11) $3 \mathrm{k}$<smiles>O=C(Oc1cncc(Cl)c1)c1ccc2[nH]ccc2c1</smiles>

(14) CE-5<smiles>O=C(/C=C/c1ccc(Cl)cc1F)N[C@@H](Cc1ccccc1)C(=O)N[C@@H](C[C@@H]1CCNC1=O)C(=O)O</smiles>

(17) $6 \mathrm{~d}$

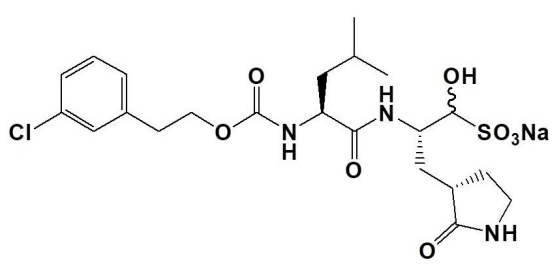

(19) GC813

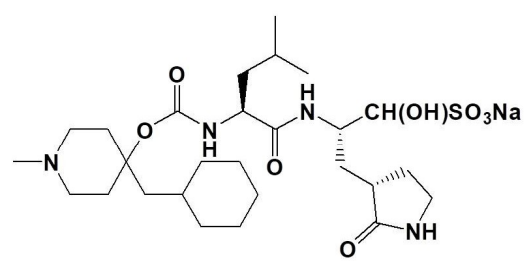

(21) 10c

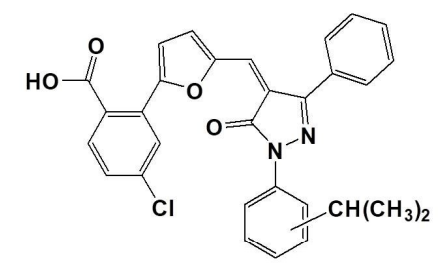

(12) $3 \mathrm{~h}$

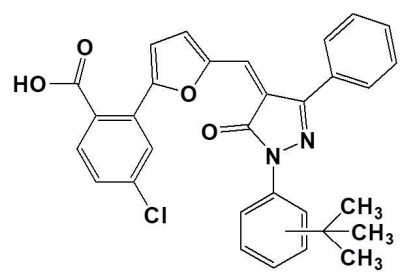

(13) $3 \mathrm{i}$<smiles>O=C(/C=C/c1cccc(Br)c1)N[C@@H](Cc1ccccc1)C(=O)N[C@@H](C[C@@H]1CCNC1=O)C(=O)O</smiles>

(15) $6 b$

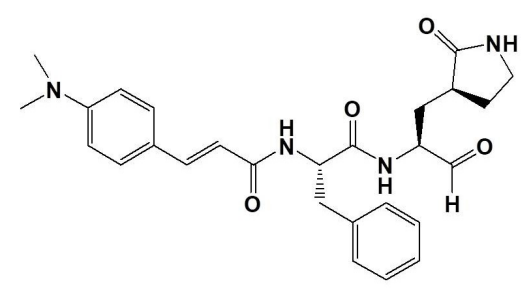

(16) $6 \mathrm{c}$

(18) GC376

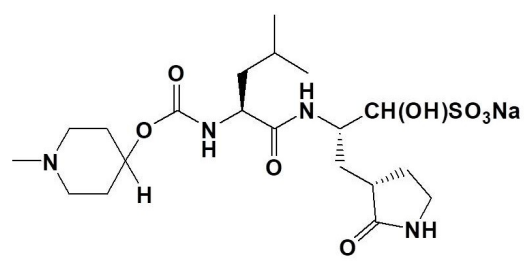

(20) 10a

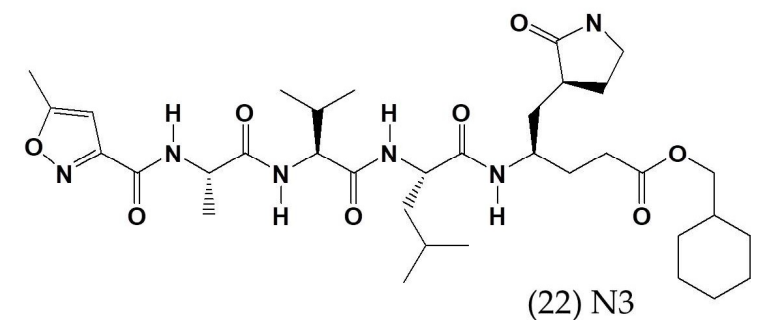

Figure 5. Cont. 


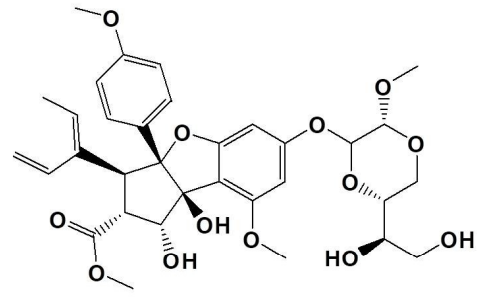

(23) Silvestrol

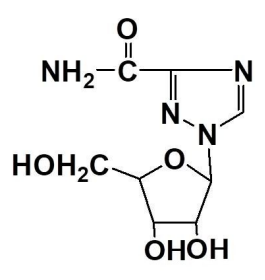

(24) Ribavirin

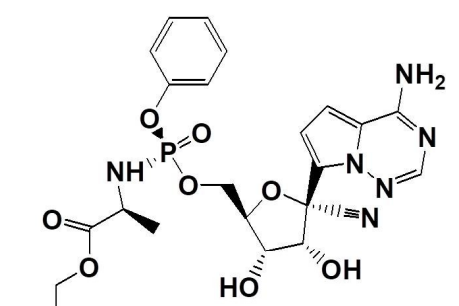

(25) GS-5734<smiles>CCC1=C(C[C@H]2NCCc3cc(OC)c(OC)cc32)C[C@H]2c3cc(OC)c(OC)cc3CCC2CC1</smiles>

(26) GS-441524<smiles>CCN(CC)CCCC(C)Nc1ccnc2cc(Cl)ccc12</smiles>

(29) Chloroquine diphosphate<smiles>CCN(CC)Cc1cc(Nc2ccnc3cc(Cl)ccc23)ccc1O</smiles>

(32) Amodiaquine dihydrochloride dehydrate
(27) Resveratrol<smiles>CCN(CCO)CCCC(C)Nc1ccnc2cc(Cl)ccc12</smiles>

(30) Hydroxychloroquine sulfate

(28) Emetine dihydrochlorid، hydrate<smiles>O[C@H](c1cc(C(F)(F)F)nc2c(C(F)(F)F)cccc12)C1CCCCN1</smiles>

(31) Mefloquine<smiles>CCOC(=O)[C@H]1O[C@@H]1C(=O)N[C@H](CC(C)C)C(=O)NCCC(C)C</smiles>

(33) E-64-D

Figure 5. Cont. 


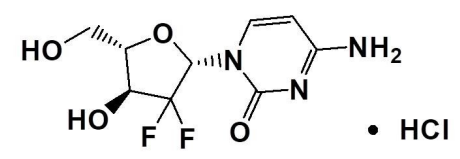

(34) Gemcitabine hydrochloride

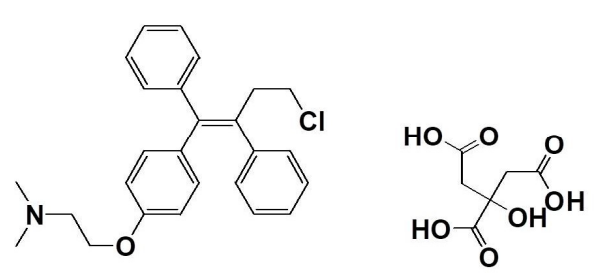

(36) Toremifene citrate

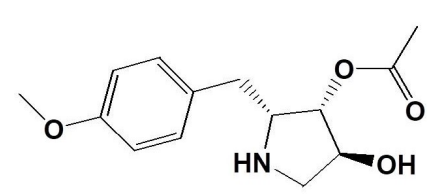

(39) Anisomycin

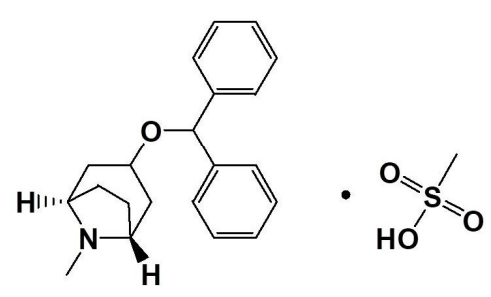

(42) Benztropine mesvlate

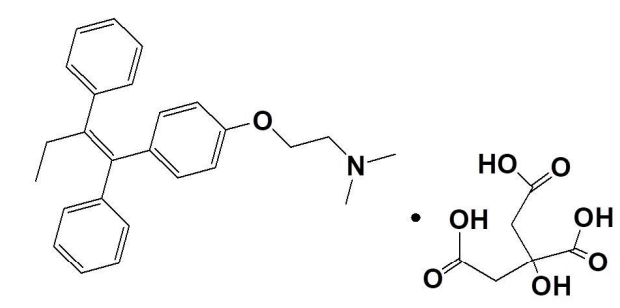

(35) Tamoxifen citrate
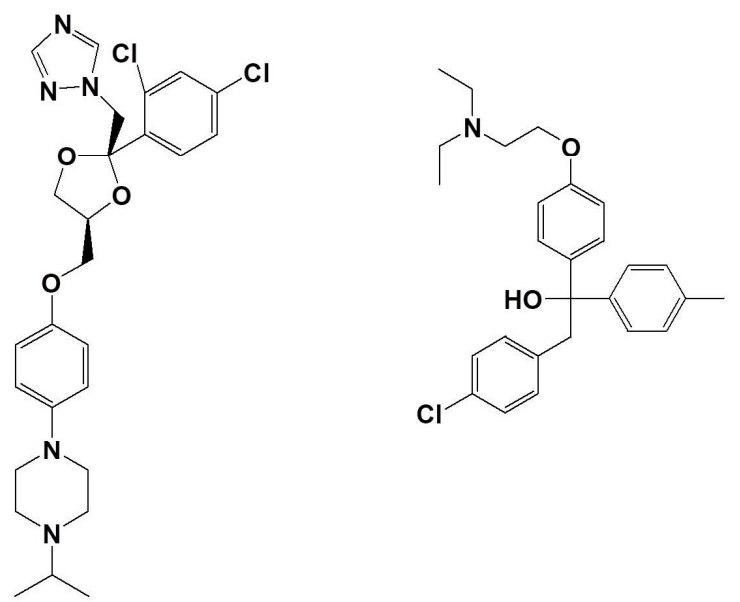

(38) Triparanol

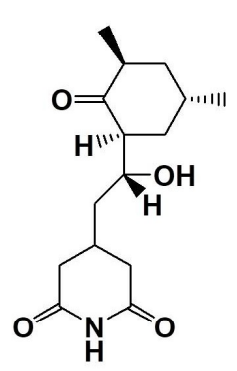

(40) Cycloheximide

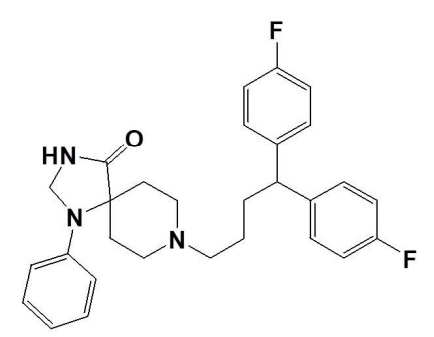

(43) Fluspirilene

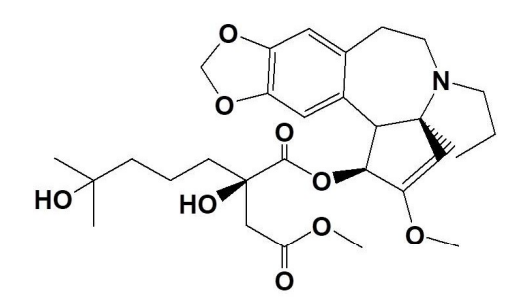

(41) Homoharringtonine

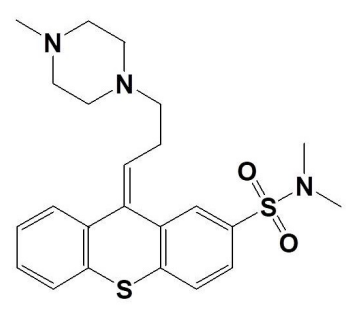

(44) Thiothixene
Figure 5. Cont. 
<smiles>COc1ccc(CCN2CCC(Nc3nc4ccccc4n3Cc3ccc(F)cc3)CC2)cc1</smiles>

(45) Fluphenazine hydrochloride

(46) Promethazine hydrochloride

(47) Astemizole

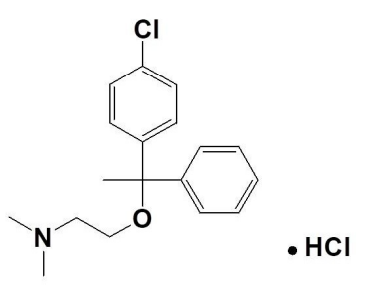

(48) Chlorophenoxamine hydrochloride<smiles>CN(C)CCCN1c2ccccc2Sc2ccc(C(F)(F)F)cc21</smiles>

(51) Triflupromazine hydrochloride

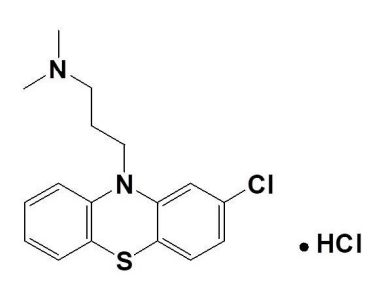

(49) Chlorpromazine hydrochloride

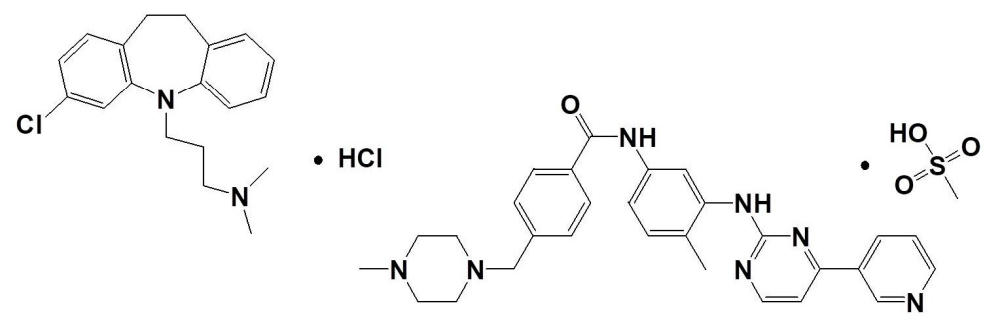

(52) Clomipramine hydrochloride

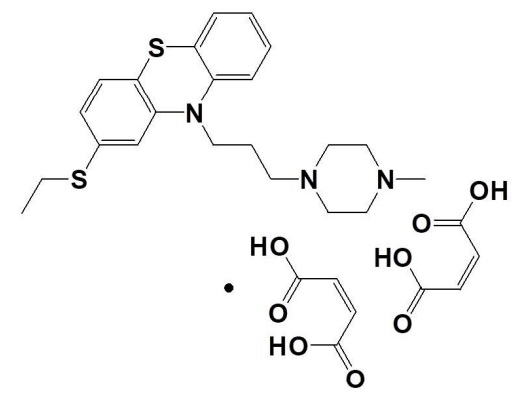

(50) Thiethyperazine maleate<smiles>Cc1nc(Nc2ncc(C(=O)Nc3c(C)cccc3Cl)s2)cc(N2CCN(CCO)CC2)n1</smiles>

(54) Dasatinib

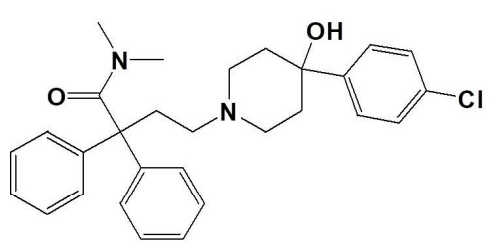

(55) Loperamide

Figure 5. Cont. 
<smiles>Cc1cccc(C)c1OCC(=O)N[C@H](Cc1ccccc1)C(O)C[C@@H](Cc1ccccc1)NC(=O)C(C(C)C)N1CCCNC1=O</smiles>

(56) Lopinavir

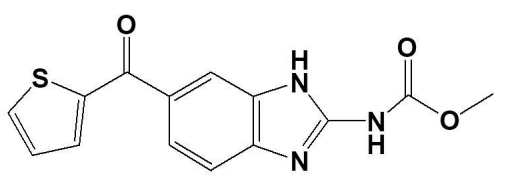

(57) Nocodazole<smiles>CCC1(C2OC(C3OC(O)(CO)C(C)CC3C)CC2C)CCC(C2(C)CCC3(CC(O)C(C)C(C(C)C(OC)C(C)C(=O)O)O3)O2)O1</smiles>

(58) Monensin

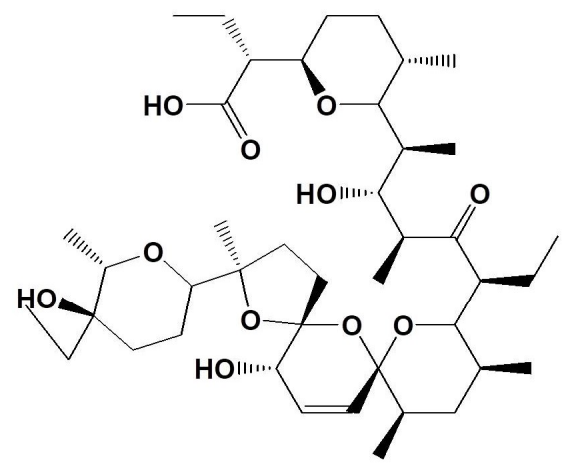

(59) Salinomycin sodium<smiles>CN(C)CCCN1c2ccccc2Sc2ccc(Cl)cc21</smiles>

(60) Chlorpromazine hydrochloride<smiles>C=CCn1c(S)nnc1CSc1ccccc1[N+](=O)[O-]</smiles>

(61) SSYA10-001<smiles>CC(C)(C)c1cc(C(=O)/C(C#N)=N/Nc2cccc(Cl)c2)no1</smiles>

(62) ESI-09<smiles>COc1c(C)c2c(c(O)c1C/C=C(\C)CCC(=O)O)C(=O)OC2</smiles>

(63) Mycophenolic acid<smiles>CC(C)(C)OC(=O)c1ccccc1C(=O)N/C(=C\c1ccccc1)C(=O)N1CCC(O)(c2ccc(Br)cc2)CC1</smiles>

(64) K22

Figure 5. Cont. 
<smiles>Nc1ncnc2c(N3[C@H](O)[C@H](O)[C@H]3CO)c[nH]c12</smiles>

(65) BCX4430<smiles>COc1nc(N)ncc1-c1cn(COCO)cn1</smiles>

(66) target fleximer analogue 2<smiles>NC1CONC1=O</smiles>

(67) Cyclosporine<smiles>CN1CCN(CCOc2cc(OC3CCOCC3)c3c(Nc4c(Cl)ccc5c4OCO5)ncnc3c2)CC1</smiles>

(68) Saracatinib

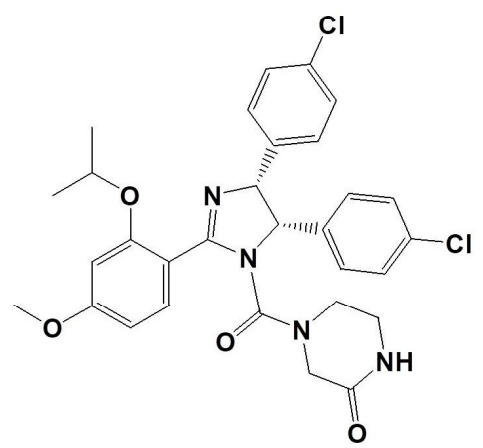

(69) Nutlin-3<smiles>CCN(CC)Cc1cc(Nc2ccnc3cc(Cl)ccc23)ccc1O</smiles>

(70) Amodiaquine dihydrochloride

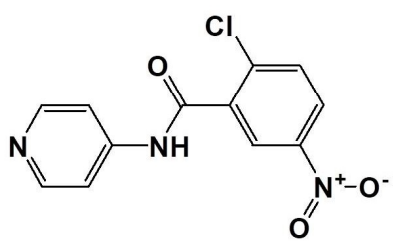<smiles>CN1CCN(c2nc(C3=C(c4c[nH]c5ccccc45)C(=O)NC3=O)c3ccccc3n2)CC1</smiles>

(71) Sotrastaurin

(72) Dosulepin hydrochloride

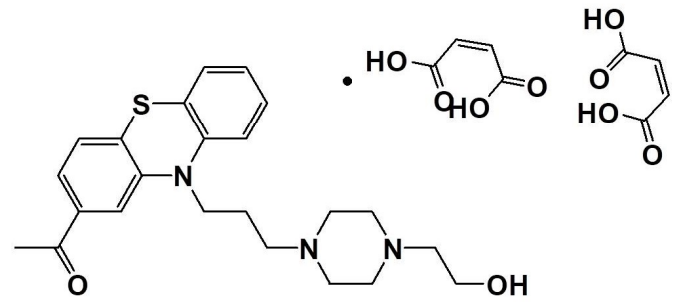

(73) N1-(4-pyridyl)-2-chloro-5-nitrobenzamide (74) Acetophenazine maleate

Figure 5. Cont. 
<smiles>COc1ccc2c(c1)N(CC(C)CN(C)C)c1ccccc1S2</smiles>

(75) Methotrimeprazine maleate salt

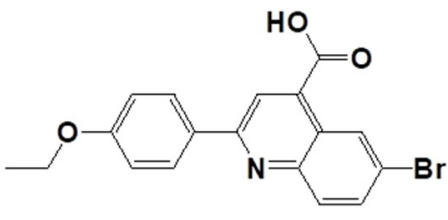

(76) FA-613

Figure 5. Chemical structure formulae of small-molecule inhibitors of MERS-CoV described in this review.

\subsection{MERS-CoV Replication Inhibitors}

\subsubsection{MERS-CoV Inhibitors Targeting Papain-Like Protease}

Papain-like protease is a cysteine protease that uses the thiol group of cysteine as a nucleophile to attack the carbonyl group of the scissile peptide bond [38,39]. The genome of MERS-CoV encodes two polyproteins, ppla and pplb, which are processed by papain-like protease (PL pro) and 3C-like protease (3CLro) [40]. MERS-CoV has only one papain-like protease, as does SARS-CoV, while other

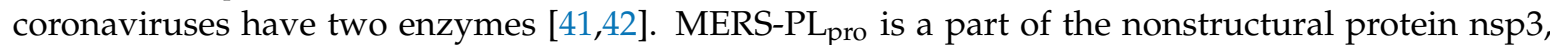
which includes three domains-namely, ubiquitin-like domain (UBL), a catalytic triad consisting of C1594-H1761-D1776, and the ubiquitin-binding domain (UBD) at the zinc finger-according

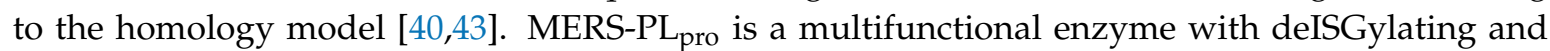
deubiquitinating (DUB) activities [43], but it can also block the interferon regulatory factor 3 (IRF3) pathway $[43,44]$.

Disulfiram, a drug used in alcohol aversion therapy, has been approved by the U.S. Food and Drug Administration (FDA) since 1951 (Figure 5(10)). It can inhibit the activity of some enzymes, such as urease [45], methyltransferase [46], and kinase [45], all by reacting with cysteine residues, suggesting broad-spectrum characteristics [47]. Notably, disulfiram also acts as an allosteric inhibitor of MERS-CoV papain-like protease [47]. Multiple inhibition assays also support a kinetic mechanism by which disulfiram, together with 6TG (6-thioguanine) and/or MPA (mycophenolic acid), can synergistically inhibit MERS-CoV papain-like protease [47]. Hence, the recombination of three clinically available drugs could feasibly be used to treat MERS-CoV infection.

\subsubsection{MERS-CoV Inhibitors Targeting 3C-Like Protease}

The active site of MERS-3CL $L_{\text {pro }}$ can be divided into subsites S1-S6 [48]. Subsite S1 consists of vital catalytic residue Cys145 with His41 to process polyproteins at 11 conserved Gln sites, followed by small amino acids like Ala, Ser, or Gly [49]. Another crucial component of the S1 subsite is the oxyanion hole formed by the interaction of a carboxylate anion of conserved Gln with Gly143, Ser144, and Cys145, which stabilizes the transition state during proteolysis [50,51]. Glu166 at the entrance of the pocket interacts via H-bond with the Ne2 of the conserved Gln [50]. The S2 and S4 subsites contain hydrophobic and bulky side chains such as Val, Leu, or Phe. Subsites S5 and S6 are near the surface of the active site and have little participation in substrate binding [48]. 
Table 2. Small molecule viral inhibitors against MERS-CoV.

\begin{tabular}{|c|c|c|c|c|c|}
\hline Inhibitor & Testing Model & Cell Lines & $\mathrm{EC}_{50}(\mu \mathrm{M})$ & $\mathrm{CC}_{50}(\mu \mathrm{M})$ & Ref. \\
\hline \multicolumn{6}{|c|}{ Inhibitors blocking the binding between virus and host cells } \\
\hline ADS-J1 & In vitro & NBL-7 and Huh-7 cells & 0.6 & 26.9 & [27] \\
\hline \multicolumn{6}{|c|}{ Inhibitors disrupting endocytosis } \\
\hline Chlorpromazine & In vitro & Huh-7 cells & $\begin{array}{c}23.33 \pm 2.89^{\mathrm{a}} \\
49 \pm 1.2 \\
9.514\end{array}$ & $\begin{array}{c}>40 \\
21.3 \pm 1.0\end{array}$ & {$[5-7,26]$} \\
\hline Promethazine & In vitro & Huh-7 cells & $\begin{array}{c}16.67 \pm 7.22^{\mathrm{a}} \\
11.802\end{array}$ & $>40$ & {$[7,26]$} \\
\hline Fluphenazine & In vitro & Huh-7 cells & $\begin{array}{c}15.00 \pm 4.33^{\mathrm{a}} \\
5.868\end{array}$ & $\sim 40$ & {$[7,26]$} \\
\hline K11777 & In vitro & Vero cells & 0.046 & $>10$ & [32] \\
\hline Camostat & In vitro & Vero-TMPRSS2 cells & $\sim 1$ & - & [31] \\
\hline Ouabain & In vitro & Huh-7 cells & $\sim 0.05$ & - & [35] \\
\hline Bufalin & In vitro & Huh-7 cells & $0.01-0.015$ & - & [35] \\
\hline Dihydrotanshinone & In vitro & - & $0.5-1 \mu \mathrm{g} / \mathrm{mL}$ & - & [36] \\
\hline \multicolumn{6}{|c|}{ Inhibitors interrupting MERS-CoV MERS-CoV RNA replication and translation } \\
\hline Disulfiram & In vitro & - & $22.7 \pm 0.5$ & - & [47] \\
\hline $3 \mathbf{k}$ & In vitro & - & $5.8 \pm 1.6$ & - & [48] \\
\hline $3 \mathrm{~h}$ & In vitro & - & $7.3 \pm 2.1$ & - & [48] \\
\hline $3 \mathbf{i}$ & In vitro & - & $7.4 \pm 2.2$ & - & [48] \\
\hline CE-5 & In vitro & HEK293T cells & $\sim 12.5$ & - & [53] \\
\hline $6 b$ & In vitro & Huh-7 cells & $1.4 \pm 0.0$ & $>100$ & [54] \\
\hline $6 c$ & In vitro & Huh-7 cells & $1.2 \pm 0.6$ & $>100$ & [54] \\
\hline $6 d$ & In vitro & Huh-7 cells & $0.6 \pm 0.0$ & $58.6 \pm 1.2$ & [54] \\
\hline GC376 & In vitro & - & $\begin{array}{c}1.56 \pm 0.09 \\
0.9\end{array}$ & $>150$ & {$[52,55]$} \\
\hline GC813 & In vitro & - & 0.5 & - & {$[52]$} \\
\hline $10 a$ & In vitro & Vero81 cells & 0.5 & $>100$ & [52] \\
\hline $10 \mathrm{c}$ & In vitro & Vero81 cells & 0.8 & $>100$ & [52] \\
\hline N3 & In vitro & - & $0.28 \pm 0.02$ & - & [56] \\
\hline
\end{tabular}


Table 2. Cont.

\begin{tabular}{|c|c|c|c|c|c|}
\hline Inhibitor & Testing Model & Cell Lines & $\mathrm{EC}_{50}(\mu \mathrm{M})$ & $\mathrm{CC}_{50}(\mu \mathrm{M})$ & Ref. \\
\hline \multicolumn{6}{|c|}{ Inhibitors with undefined mechanisms } \\
\hline Silvestrol & In vitro & MRC -5 cells & 0.0013 & 0.4 & [57] \\
\hline GS-5734 & In vitro & HAE cells & $0.074 \pm 0.023$ & $>10$ & [58] \\
\hline GS-441524 & In vitro & HAE cells & $0.86 \pm 0.78$ & $>100$ & [58] \\
\hline Chloroquine & In vitro & MDMs and MDDCs cells & $\begin{array}{l}3.0 \pm 1.1 \\
\quad 6.275\end{array}$ & $58.1 \pm 1.1$ & {$[7,59]$} \\
\hline Emetine dihydrochloride hydrate & In vitro & Vero E6 cells & 0.014 & - & [7] \\
\hline Hydroxychloroquine sulfate & In vitro & Vero E6 cells & 8.279 & - & [7] \\
\hline Mefloquine & In vitro & Vero E6 cells & 7.416 & - & [7] \\
\hline $\begin{array}{l}\text { Amodiaquine dihydrochloride } \\
\text { dehydrate }\end{array}$ & In vitro & Vero E6 cells & 6.212 & - & {$[7]$} \\
\hline E-64-D & In vitro & Vero E6 cells & 1.275 & - & [7] \\
\hline Gemcitabine hydrochloride & In vitro & Vero E6 cells & 1.216 & - & [7] \\
\hline Tamoxifen citrate & In vitro & Vero E6 cells & 10.117 & - & [7] \\
\hline Toremifene citrate & In vitro & Vero E6 cells & 12.915 & - & [7] \\
\hline Terconazole & In vitro & Vero E6 cells & 12.203 & - & [7] \\
\hline Triparanol & In vitro & Vero E6 cells & 5.283 & - & [7] \\
\hline Anisomycin & In vitro & Vero E6 cells & 0.003 & - & [7] \\
\hline Cycloheximide & In vitro & Vero E6 cells & 0.189 & - & [7] \\
\hline Homoharringtonine & In vitro & Vero E6 cells & 0.0718 & - & [7] \\
\hline Benztropine mesylate & In vitro & Vero E6 cells & 16.627 & - & [7] \\
\hline Fluspirilene & In vitro & Vero E6 cells & 7.477 & - & [7] \\
\hline Thiothixene & In vitro & Vero E6 cells & 9.297 & - & [7] \\
\hline Astemizole & In vitro & Vero E6 cells & 4.884 & - & [7] \\
\hline Chlorphenoxamine hydrochloride & In vitro & Vero E6 cells & 12.646 & & [7] \\
\hline Thiethylperazine maleate & In vitro & Vero E6 cells & 7.865 & - & [7] \\
\hline Triflupromazine hydrochloride & In vitro & Vero E6 cells & 5.758 & - & [7] \\
\hline Clomipramine hydrochloride & In vitro & Vero E6 cells & 9.332 & - & [7] \\
\hline Imatinib mesylate & In vitro & Vero E6 cells & 17.689 & - & [7] \\
\hline Dasatinib & In vitro & Vero E6 cells & 5.468 & - & [7] \\
\hline Loperamide & In vitro & Vero E6 cells & $4.8 \pm 1.5$ & $15.5 \pm 1.0$ & [7] \\
\hline Lopinavir & In vitro & Vero E6 cells & $8.0 \pm 1.5$ & $24.4 \pm 1.0$ & {$[7]$} \\
\hline SSYA10-001 & In vitro & Vero E6 cells & $\sim 25$ & $>500$ & [60] \\
\hline ESI-09 & In vitro & Calu-3 and Vero E6 cells & $5-10$ & $>50$ & [61] \\
\hline Mycophenolic acid & In vitro & Vero E6 cells & 2.87 & - & [60] \\
\hline
\end{tabular}


Table 2. Cont.

\begin{tabular}{|c|c|c|c|c|c|}
\hline Inhibitor & Testing Model & Cell Lines & $\mathrm{EC}_{50}(\mu \mathrm{M})$ & $\mathrm{CC}_{50}(\mu \mathrm{M})$ & Ref. \\
\hline \multicolumn{6}{|c|}{ Inhibitors with undefined mechanisms } \\
\hline BCX4430 & In vitro & - & 68.4 & $>100$ & [62] \\
\hline Fleximer analogues 2 & In vitro & $\begin{array}{l}\text { Vero cells } \\
\text { Huh-7 cells }\end{array}$ & $\begin{array}{l}23 \pm 0.6 \\
27 \pm 0.0\end{array}$ & $\begin{array}{r}71 \pm 14 \\
149 \pm 6.8\end{array}$ & {$[63]$} \\
\hline Nutlin-3 & In vitro & Huh-7 cells & $6.9 \pm 1.4$ & $26.8 \pm 1.6$ & [64] \\
\hline Amodiaquine dihydrochloride & In vitro & Huh-7 cells & $2.1 \pm 0.7$ & $12.3 \pm 5.9$ & [64] \\
\hline Saracatinib & In vitro & Huh-7 cells & $2.9 \pm 0.6$ & $57 \pm 5.5$ & [64] \\
\hline Sotrastaurin & In vitro & Huh-7 cells & $9.7 \pm 3.3$ & $>50$ & {$[64]$} \\
\hline Acetophenazine maleate & In vitro & Huh-7 cells & $11.2 \pm 5.0$ & $23.6 \pm 3.8$ & [64] \\
\hline Dosulepin hydrochloride & In vitro & Huh-7 cells & $3.4 \pm 0.0$ & $28.9 \pm 0.0$ & [64] \\
\hline Methotrimeprazine maleate salt & In vitro & Huh-7 cells & $2.5 \pm 0.0$ & $24.5 \pm 0.0$ & {$[64]$} \\
\hline N1-(4-pyridyl)-2-chloro-5-nitrobenzamide & In vitro & Huh-7 cells & $10.5 \pm 0.3$ & $>50$ & {$[64]$} \\
\hline FA-613 & In vitro & Huh-7 cells & $10.2 \pm 0.2$ & - & {$[65]$} \\
\hline
\end{tabular}

a $50 \%$ effective concentration $\left(\mathrm{EC}_{50}\right)$ values of inhibiting cell-cell fusion. "-" indicates data not available. 
Polyproteins pp1a and pp1b are processed by $3 \mathrm{CL}_{\text {pro }}$ ( 11 cleavage sites) and $\mathrm{PL}_{\text {pro }}$ ( 3 cleavage sites), resulting in 16 mature nonstructural proteins, including RNA-dependent RNA polymerase (RdRp) and helicase, which play important roles in the transcription and replication of coronaviruses $[40,52]$. Therefore, both proteases are essential for viral replication, making them attractive targets for drug development [52].

The analogues of hits of neuraminidase (NA) inhibitors on MERS-CoV $3 \mathrm{CL}_{\text {pro }}$ have been synthesized and showed average-to-good inhibition of MERS-3CL $\mathrm{L}_{\text {pro }}$. The better one is the compound 3k with an $\mathrm{EC}_{50}$ of $5.8 \mu \mathrm{M}$ (Table 2; Figure 5(11)) [48]. Another two are compounds $3 \mathbf{h}$ (Figure 5(12)) and 3i (Figure 5(13)) with $\mathrm{EC}_{50}$ values of 7.3 and $7.4 \mu \mathrm{M}$, repsectively (Table 2) [48]. Furthermore, researchers have concluded that pharmacophores phenyl at R3 and carboxylate, either at R1 or R4, are essential for the antiviral activity [48]. Since the modification of rings A and B is well tolerated, these rings can be further altered to enhance the activity of the compounds. The SARS-CoV 3CL pro inhibitor CE-5 can block the function of the MERS-CoV 3CLpro (Figure 5(14)) [53]. Treatment with CE-5 inhibited the activity of MERS-CoV $3 \mathrm{CL}_{\text {pro }}$ to $30 \%$ of that of DMSO-treated cells at a maximum dose of $50 \mu \mathrm{M}$ [53]. The endpoint evaluation of CE-5 indicated an $\mathrm{EC}_{50}$ of $\sim 12.5 \mu \mathrm{M}$ in cell culture (Table 2) [53].

Peptidomimetic inhibitors of enterovirus $(\mathbf{6 b}, \mathbf{6 c}$, and $\mathbf{6 d})$ inhibit MERS-CoV with $\mathrm{EC}_{50}$ values ranging from 1.7 to $4.7 \mu \mathrm{M}$, as shown by enzymatic assay (Figure 5(15), (16), (17)) [54]. As shown in Table 1, compounds $\mathbf{6 b} \mathbf{b} \mathbf{6}$, and $\mathbf{6} \mathbf{d}$ efficiently suppressed viral replication with $\mathrm{EC}_{50}$ values of $1.4,1.2$, and $0.6 \mu \mathrm{M}$, respectively, after performing a cytopathic inhibition assay using MERS-CoV-infected Huh-7 cells (Table 2) [54].

GC376, a dipeptidyl transition state $3 \mathrm{CL}_{\text {pro }}$ inhibitor, can substantially inhibit the activity of MERS-CoV 3CL pro with an $\mathrm{EC}_{50}$ of $1.6 \mu \mathrm{M}$ by fluorescence resonance energy transfer (FRET) assay (Table 2; Figure 5(18)) [55].

GC813 as well as its synthesizing extended compounds 10a and 10c exhibit inhibition for MERS-CoV with $\mathrm{EC}_{50}$ values of $0.5 \mu \mathrm{M}, 0.5 \mu \mathrm{M}$, and $0.8 \mu \mathrm{M}$ in cell culture (Table 2; Figure 5(18), (19), (20), (21)) [52].

N3, a broad-spectrum anti-CoV inhibitor, can inhibit the proteolytic activity of MERS-CoV 3CLpro by binding with the interface of domain I and II of MERS-CoV 3CL pro with an $\mathrm{EC}_{50}$ of about $0.3 \mu \mathrm{M}$ (Table 2; Figure 5(22)) [56].

\subsection{Other Small-Molecule Inhibitors with Defined or Undefined Mechanisms of Action}

Silvestrol, an eIF4A inhibitor, can inhibit MERS-CoV infection with an $\mathrm{EC}_{50}$ of $1.3 \mathrm{nM}$, as shown by plaque assay in MRC- 5 cells and $\mathrm{CC}_{50}$ of $400 \mathrm{nM}$ by MTT assay in peripheral blood mononuclear cells (PBMCs) (Table 2; Figure 5(23)) [57]. Silvestrol has broad-spectrum antiviral activity via the inhibition of the expression of $\mathrm{CoV}$ structural and nonstructural proteins $(\mathrm{N}, \mathrm{nsp} 8)$ and the formation of viral replication/transcription complexes [57].

The combination of interferon- $\alpha 2 b$ and ribavirin can effectively reduce MERS-CoV replication in vitro and in vivo (Table 2; Figure 5(24)) [6]. Rhesus macaques treated with IFN- $\alpha 2 b$ and ribavirin $8 \mathrm{~h}$ after MERS-CoV infection showed improved clinical parameters with no or very mild radiographic evidence of pneumonia compared with untreated macaques [6]. Moreover, treated macaques showed lower levels of systemic (serum) and local (lung) proinflammatory markers in addition to fewer viral genome copies, distinct gene expression, and less severe histopathological changes in the lungs [6].

GS-5734 (Remdesivir), the monophosphoramidate prodrug of the C-adenosine nucleoside analogue GS-441524, can inhibit the replication of the model $\beta$-coronavirus murine hepatitis virus (MHV) and RNA synthesis in wild-type (WT) virus, while an nsp14 ExoN (-) mutant lacking proofreading demonstrated increased susceptibility to GS-5734 (Figure 5(25)) [58]. GS-5734 also inhibits MERS-CoV infection with an $\mathrm{EC}_{50}$ of $0.074 \pm 0.023 \mu \mathrm{M}$ and $\mathrm{CC}_{50}$ of $>10 \mu \mathrm{M}$ in human amniotic epithelial (HAE) cells (Table 2) [58]. Furthermore, GS-5734 acts at the early post-infection stage to decrease viral RNA levels, whereas delaying the addition of GS-5734 until $24 \mathrm{~h}$ post-infection 
resulted in decreased viral titer in HAE cell cultures at 48 and $72 \mathrm{~h}$ post-infection [58]. The nucleotide analogue GS-441524 also inhibits the infection of MERS-CoV with an $\mathrm{EC}_{50}$ of $0.9 \mu \mathrm{M}$ and a $\mathrm{CC}_{50}$ of $>100 \mu \mathrm{M}$ in HAE cells (Table 2; Figure 5(26)) [58].

Resveratrol was found to significantly inhibit MERS-CoV infection as well as prolong cellular survival after virus infection (Figure 5. (27)) [66]. It was found that resveratrol could reduce RNA levels and infection titers in Vero cells [66]. Although resveratrol has minimal cytotoxicity, even at the high concentration of $250 \mu \mathrm{M}$, it can be ignored when compared to the much more severe toxicity of MERS-CoV infection [66].

A series of FDA-approved compounds were screened against MERS-CoV (Table 2) by cell-based ELISA assay (Figure 5(28-56)) [7]. Pharmaceuticals that inhibit MERS-CoV include neurotransmitter inhibitors, estrogen receptor antagonists, kinase signaling inhibitors, inhibitors of lipid or sterol metabolism, protein processing inhibitors, inhibitors of DNA synthesis/repair, as well as inhibitors of ion transport, cytoskeleton (specifically tubulin), and apoptosis [7]. Antiparasitics and antibacterials are two classes of pharmaceuticals, the functions of which are not obviously linked to coronaviruses, or viruses in general, but nonetheless show antiviral activity against MERS-CoV.

Nocodazole, targeting the cytoskeleton, specifically interferes with microtubule polymerization. It is an antimitotic drug developed for the treatment of cancer, but it was found to show high activity against MERS-CoV (Figure 5(57)) [67,68]. Monensin and salinomycin sodium, two of the nine ion channel inhibitors, have inhibitory activity against MERS-CoV, indicating that MERS-CoV may be susceptible to ionophore activities (Figure 5 (58), (59)). Chlorpromazine and chloroquine appear to target host factors, rather than viral proteins specifically, and the treatment of viral infections in patients aimed at host factors could reconfigure overt manifestations of viral pathogenesis into a less virulent subclinical infection and lower adverse disease outcome (Figure 5(60), (29)) [34,69].

Loperamide, an antidiarrheal opioid receptor agonist that reduces intestinal motility, also inhibits the replication of MERS-CoV at low-micromolar concentrations $(3.3-6.3 \mu \mathrm{M})$ in vitro (Table 2; Figure 5(55)) [34]. Lopinavir, the HIV-1 protease inhibitor, inhibits MERS-CoV replication with an $\mathrm{EC}_{50}$ of $8 \mu \mathrm{M}$ (Table 2; Figure 5(56)) [34].

SSYA10-001 inhibits MERS-CoV replication with an $\mathrm{EC}_{50}$ of $\sim 25 \mu \mathrm{M}$ in Vero E6 cells (Table 2; Figure 5(61)) [70]. Molecular modeling data suggest that SSYA10-001 can be docked with a comparable "Glide" score [70].

ESI-09 can reduce virus yield by inhibiting cAMP signaling in a cell type-independent manner (Figure 5(62)) [61]. The concentration of MERS-CoV inhibition by ESI-09 was found with an $\mathrm{EC}_{50}$ of 5 to $10 \mu \mathrm{M}$ and a $\mathrm{CC}_{50}>50 \mu \mathrm{M}$ for both Calu-3 and Vero E6 cells by using the lactate dehydrogenase (LDH)-based cytotoxicity assay [62]. In addition, the undetectable cytopathic effect (CPE) and minimal expression of viral antigen indicated that Calu-3 cells treated with ESI-09 were almost fully protected [61].

Mycophenolic acid (MPA) can strongly reduce MERS-CoV replication by inhibiting inosine monophosphate dehydrogenase (IMPDH) and guanine monophosphate synthesis with an $\mathrm{EC}_{50}$ of $2.87 \mu \mathrm{M}$ by cell-based ELISA in Vero E6 cells (Table 2; Figure 5(63)) [60].

$\mathrm{K} 22$ is a spectrum inhibitor which can inhibit MERS-CoV replication by reducing the formation of double membrane vesicles (DMVs) and by the near-complete inhibition of RNA synthesis (Figure 5(64)) [25,71].

BCX4430, an adenosine analogue that acts as a non-obligate RNA chain terminator to inhibit viral RNA polymerase function, can inhibit MERS-CoV infection with $\mathrm{EC}_{50}$ of $68.4 \mu \mathrm{M}$ in Vero E6 cells by highly charged ions (HCIs)-based analysis and $\mathrm{CC}_{50}$ of $>100 \mu \mathrm{M}$ by neutral-red uptake (Table 2; Figure 5(65)) [25,62].

Fleximer nucleoside analogues of acyclovir are doubly flexible nucleoside analogues based on the acyclic sugar scaffold of acyclovir and the flex-base moiety in fleximers responsible for inhibiting RNA-dependent RNA polymerase (RdRp) [25,63]. The target fleximer analogue 2 can 
inhibit MERS-CoV infection with $\mathrm{EC}_{50}$ of $27 \mu \mathrm{M}$ and $\mathrm{CC}_{50}$ of $149 \mu \mathrm{M}$ in Huh-7 cells, but $\mathrm{EC}_{50}$ of $23 \mu \mathrm{M}$ and $\mathrm{CC}_{50}$ of $71 \mu \mathrm{M}$ in Vero cells (Table 2; Figure 5(66)) [63].

Interferon alpha1 (IFN- $\alpha 1$ ) and cyclosporine (CsA) have additive or synergistic effects in limiting MERS-CoV replication in ex vivo cultures of human bronchus (Figure 5(67)) [72]. In addition, the combined treatment of IFN- $\alpha 1$ and CsA has the most potent effect on inducing interferon-stimulated genes (ISGs) in both lung (24 hpi) and bronchial (56 hpi) tissues [72].

Saracatinib, a potent inhibitor of the Src-family of tyrosine kinases (SFK), potently inhibits MERS-CoV with an $\mathrm{EC}_{50}$ of about $3 \mu \mathrm{M}$ in Huh-7 cells (Table 2; Figure 5(68)) [64]. It possibly inhibits MERS-CoV replication through the suppression of SFK signaling pathways at the early stages of the viral life cycle [64]. In addition, another seven compounds, primarily classified as antiprotozoal, anticancer, and antipsychotic, were also determined by complete dose-response analyses (Table 2; Figure 5(69-75)) [64].

A spectrum-inhibitor, FA-613, can inhibit MERS-CoV with an $\mathrm{EC}_{50}$ of $\sim 10 \mu \mathrm{M}$ in the interferon-competent cell line of Huh-7 cells, as shown by MTT assay (Table 2; Figure 5(76)) [65].

\section{Strategies for Developing Small-Molecule MERS-CoV Inhibitors}

The luciferase-based biosensor assay is a cell-based screening assay for selecting MERS-CoV-specific or broad-spectrum coronavirus $\mathrm{PL}_{\text {pro }}$ and $3 \mathrm{CL}_{\text {pro }}$ inhibitors [53]. HEK293T cells were transfected by two artificial plasmids: protease expression plasmids and biosensor expression plasmids [53]. Protease expression plasmids contain the sequence of MERS-CoV PL the nonstructural proteins nsp4 and nsp5, as well as the $\mathrm{N}$-terminal 6 region. Biosensor expression plasmids contain a circularly permuted Photuris pennsylvanica luciferase and the amino sequence of cleavage site of $\mathrm{PL}_{\text {pro }}$ or $3 \mathrm{CL}_{\text {pro }}$ [53]. After cell transfection and coexpression of a MERS-CoV protease domain with a cleavage-activated luciferase substrate, transfected live cells allow for both endpoint evaluation and live cell imaging profiles of protease activity [53]. This novel method can be performed in a biosafety level 2 research laboratory to evaluate the ability to inhibit the CoV protease activity of existing and new drugs [53].

Pseudovirus-based screening assays have been developed for identifying antiviral compounds in the MERS-CoV life cycle without using infectious viruses. The MERS-CoV pseudovirus allows for single-cycle infection of a variety of cells expressing DPP4, and results are consistent with those from a live MERS-CoV-based inhibition assay. More importantly, the pseudovirus assay can be carried out in a BSL-2, rather than a BSL-3 facility [9]. VSV- and HIV-luciferase pseudotyped with the MERS-CoV S protein are two more approaches [27].

Structure-Guided Design and Optimization of Small Molecules is a strategy that involves embodying a piperidine moiety as a design element to attain optimal pharmacological activity and protein kinase property [52]. This strategy permits the resultant hybrid inhibitor to participate in favorable binding interactions with the $\mathrm{S} 3$ and $\mathrm{S} 4$ subsites of $3 \mathrm{CL}_{\text {pro }}$ by attaching the piperidine moiety to a dipeptidyl component [52].

Ubiquitin-like domain 2 (Ubl2) is immediately adjacent to the $\mathrm{N}$-terminus of the $\mathrm{PL}_{\text {pro }}$ domain in coronavirus polyproteins. In the past, the role of Ubl2 in PL pro has remained undefined. However, evidence indicates that removing the Ubl2 domain from MERS PL pro has no effect on its ability to process the viral polyprotein or act as an interferon antagonist, which involves deubiquitinating and deISGylating cellular proteins [73].

Analyzing the transcriptome of hosts infected with MERS-CoV can provide insight into how MERS-CoV infection influences and interacts with host cells. Josset et al. [74] infected a lung epithelial cell line, Calu3, with MERS-CoV and analyzed the transcriptome to identify inhibitory compounds resident in host factors that could be exploited as antiviral therapeutics. This approach can be used to identify host factors beneficial for virus propagation, thus establishing appropriate targets for existing or new antiviral inhibitors. 


\section{Conclusions}

As a positive-sense, single-stranded RNA virus, MERS-CoV utilizes host cellular components to accomplish various physiological processes, including viral entry, genomic replication, and the assembly and budding of virions, thereby resulting in pathological damage to the host. Therefore, various stages of virus life cycle could be potential targets for developing small-molecule antiviral inhibitors. Inhibitors blocking MERS-CoV entry into host cells, viral protease inhibitors, and inhibitors targeting host cells and many other small-molecule inhibitors with defined or undefined mechanisms of action are summarized in this review.

Any compounds that interfere with virus infection may be harmful to host cells. Therefore, the establishment of a safety profile is essential. Furthermore, an antiviral inhibitor should effectively inhibit the growth of the virus because a small amount of virion replication can lead to resistant mutations. The advantages of small-molecule inhibitors include low price, stability, and the convenience of oral administration. Three main approaches are currently used to develop MERS-CoV small-molecule inhibitors. The first is the de novo synthesis of inhibitors targeting the unique structure in the proteins of MERS-CoV appearing in its infection process. The second approach involves screening inhibitors against MERS-CoV infection from an existing drug database by various chemical synthesis strategies. The third approach involves changing the chemical group of a fully developed drug to enhance its pharmacological activity against MERS-CoV. More novel strategies in improving the efficacy of screening small-molecule inhibitors are anticipated to reduce the threat of future MERS-CoV infections.

Author Contributions: R.L., L.W., N.Z., X.D., M.S., Y.S., L.H., and C.H. drafted the manuscript. T.Y., S.J., and F.Y. revised and edited the manuscript.

Funding: This work was supported by grants from the National Natural Science Foundation of China (81501735 and 81601761), Hebei Province's Program for Talents Returning from Studying Overseas (CN201707), a starting grant from Hebei Agricultural University (ZD2016026), and the Program for Youth Talent of Higher Learning Institutions of Hebei Province (BJ2018045).

Conflicts of Interest: The authors declare no conflict of interest.

\section{References}

1. Cotten, M.; Watson, S.J.; Zumla, A.I.; Makhdoom, H.Q.; Palser, A.L.; Ong, S.H.; Al Rabeeah, A.A.; Alhakeem, R.F.; Assiri, A.; Al-Tawfiq, J.A.; et al. Spread, circulation, and evolution of the middle east respiratory syndrome coronavirus. mBio 2014, 5, e01062-13. [CrossRef] [PubMed]

2. Chan, J.F.; Lau, S.K.; Woo, P.C. The emerging novel middle east respiratory syndrome coronavirus: The "knowns" and "unknowns". J. Formos. Med. Assoc. 2013, 112, 372-381. [CrossRef] [PubMed]

3. Arabi, Y.M.; Arifi, A.A.; Balkhy, H.H.; Najm, H.; Aldawood, A.S.; Ghabashi, A.; Hawa, H.; Alothman, A.; Khaldi, A.; Al Raiy, B. Clinical course and outcomes of critically ill patients with middle east respiratory syndrome coronavirus infection. Ann. Intern. Med. 2014, 160, 389-397. [CrossRef] [PubMed]

4. Drosten, C.; Meyer, B.; Muller, M.A.; Corman, V.M.; Al-Masri, M.; Hossain, R.; Madani, H.; Sieberg, A.; Bosch, B.J.; Lattwein, E.; et al. Transmission of mers-coronavirus in household contacts. N. Engl. J. Med. 2014, 371, 828-835. [CrossRef] [PubMed]

5. Lu, L.; Liu, Q.; Du, L.; Jiang, S. Middle east respiratory syndrome coronavirus (mers-cov): Challenges in identifying its source and controlling its spread. Microbes Infect. 2013, 15, 625-629. [CrossRef]

6. Falzarano, D.; de Wit, E.; Rasmussen, A.L.; Feldmann, F.; Okumura, A.; Scott, D.P.; Brining, D.; Bushmaker, T.; Martellaro, C.; Baseler, L.; et al. Treatment with interferon-alpha2b and ribavirin improves outcome in mers-cov-infected rhesus macaques. Nat. Med. 2013, 19, 1313-1317. [CrossRef]

7. Dyall, J.; Coleman, C.M.; Hart, B.J.; Venkataraman, T.; Holbrook, M.R.; Kindrachuk, J.; Johnson, R.F.; Olinger, G.G., Jr.; Jahrling, P.B.; Laidlaw, M.; et al. Repurposing of clinically developed drugs for treatment of middle east respiratory syndrome coronavirus infection. Antimicrob. Agents Chemother. 2014, 58, 4885-4893. [CrossRef] 
8. Lu, L.; Xia, S.; Ying, T.; Jiang, S. Urgent development of effective therapeutic and prophylactic agents to control the emerging threat of middle east respiratory syndrome (mers). Emerg. Microbes Infect. 2015, 4, e37. [CrossRef]

9. Gierer, S.; Bertram, S.; Kaup, F.; Wrensch, F.; Heurich, A.; Kramer-Kuhl, A.; Welsch, K.; Winkler, M.; Meyer, B.; Drosten, C.; et al. The spike protein of the emerging betacoronavirus emc uses a novel coronavirus receptor for entry, can be activated by tmprss2, and is targeted by neutralizing antibodies. J. Virol. 2013, 87, 5502-5511. [CrossRef]

10. Bertram, S.; Dijkman, R.; Habjan, M.; Heurich, A.; Gierer, S.; Glowacka, I.; Welsch, K.; Winkler, M.; Schneider, H.; Hofmann-Winkler, H.; et al. Tmprss2 activates the human coronavirus 229e for cathepsin-independent host cell entry and is expressed in viral target cells in the respiratory epithelium. J. Virol. 2013, 87, 6150-6160. [CrossRef]

11. Du, L.Y.; Yang, Y.; Zhou, Y.S.; Lu, L.; Li, F.; Jiang, S.B. Mers-cov spike protein: A key target for antivirals. Expert Opin. Ther. Target 2017, 21, 131-143. [CrossRef] [PubMed]

12. Xia, S.; Liu, Q.; Wang, Q.; Sun, Z.W.; Su, S.; Dub, L.Y.; Ying, T.L.; Lu, L.; Jiang, S.B. Middle east respiratory syndrome coronavirus (mers-cov) entry inhibitors targeting spike protein. Virus Res. 2014, 194, $200-210$. [CrossRef] [PubMed]

13. Forni, D.; Filippi, G.; Cagliani, R.; De Gioia, L.; Pozzoli, U.; Al-Daghri, N.; Clerici, M.; Sironi, M. The heptad repeat region is a major selection target in mers-cov and related coronaviruses. Sci. Rep. 2015, 5, 14480. [CrossRef] [PubMed]

14. Gao, J.; Lu, G.; Qi, J.; Li, Y.; Wu, Y.; Deng, Y.; Geng, H.; Li, H.; Wang, Q.; Xiao, H.; et al. Structure of the fusion core and inhibition of fusion by a heptad repeat peptide derived from the s protein of middle east respiratory syndrome coronavirus. J. Virol. 2013, 87, 13134-13140. [CrossRef] [PubMed]

15. Raj, V.S.; Mou, H.; Smits, S.L.; Dekkers, D.H.; Muller, M.A.; Dijkman, R.; Muth, D.; Demmers, J.A.; Zaki, A.; Fouchier, R.A.; et al. Dipeptidyl peptidase 4 is a functional receptor for the emerging human coronavirus-emc. Nature 2013, 495, 251-254. [CrossRef] [PubMed]

16. Lu, L.; Liu, Q.; Zhu, Y.; Chan, K.H.; Qin, L.; Li, Y.; Wang, Q.; Chan, J.F.; Du, L.; Yu, F.; et al. Structure-based discovery of middle east respiratory syndrome coronavirus fusion inhibitor. Nat. Commun. 2014, 5, 3067. [CrossRef] [PubMed]

17. Xu, Y.; Lou, Z.; Liu, Y.; Pang, H.; Tien, P.; Gao, G.F.; Rao, Z. Crystal structure of severe acute respiratory syndrome coronavirus spike protein fusion core. J. Boil. Chem. 2004, 279, 49414-49419. [CrossRef]

18. Channappanavar, R.; Lu, L.; Xia, S.; Du, L.; Meyerholz, D.K.; Perlman, S.; Jiang, S. Protective effect of intranasal regimens containing peptidic middle east respiratory syndrome coronavirus fusion inhibitor against mers-cov infection. J. Infect. Dis. 2015, 212, 1894-1903. [CrossRef]

19. Tao, X.; Garron, T.; Agrawal, A.S.; Algaissi, A.; Peng, B.H.; Wakamiya, M.; Chan, T.S.; Lu, L.; Du, L.; Jiang, S.; et al. Characterization and demonstration of the value of a lethal mouse model of middle east respiratory syndrome coronavirus infection and disease. J. Virol. 2016, 90, 57-67. [CrossRef]

20. Wang, C.; Xia, S.; Zhang, P.; Zhang, T.; Wang, W.; Tian, Y.; Meng, G.; Jiang, S.; Liu, K. Discovery of hydrocarbon-stapled short alpha-helical peptides as promising middle east respiratory syndrome coronavirus (mers-cov) fusion inhibitors. J. Med. Chem. 2018, 61, 2018-2026. [CrossRef]

21. Zhao, H.; Zhou, J.; Zhang, K.; Chu, H.; Liu, D.; Poon, V.K.; Chan, C.C.; Leung, H.C.; Fai, N.; Lin, Y.P.; et al. A novel peptide with potent and broad-spectrum antiviral activities against multiple respiratory viruses. Sci. Rep. 2016, 6, 22008. [CrossRef] [PubMed]

22. Wang, C.; Zhao, L.; Xia, S.; Zhang, T.; Cao, R.; Liang, G.; Li, Y.; Meng, G.; Wang, W.; Shi, W.; et al. De novo design of alpha-helical lipopeptides targeting viral fusion proteins: A promising strategy for relatively broad-spectrum antiviral drug discovery. J. Med. Chem. 2018, 61, 8734-8745. [CrossRef] [PubMed]

23. Wang, X.; Zou, P.; Wu, F.; Lu, L.; Jiang, S. Development of small-molecule viral inhibitors targeting various stages of the life cycle of emerging and re-emerging viruses. Front. Med. 2017, 11, 449-461. [CrossRef] [PubMed]

24. Jiang, S.B.; Tao, X.R.; Xia, S.; Garron, T.; Yu, F.; Du, L.Y.; Lu, L.; Tseng, C.T.K. Intranasally administered peptidic viral fusion inhibitor protected hdpp4 transgenic mice from mers-cov infection. Lancet 2015, 386, S44. [CrossRef]

25. Zumla, A.; Chan, J.F.; Azhar, E.I.; Hui, D.S.; Yuen, K.Y. Coronaviruses-Drug discovery and therapeutic options. Nat. Rev. Drug Discov. 2016, 15, 327-347. [CrossRef] 
26. Liu, Q.; Xia, S.; Sun, Z.; Wang, Q.; Du, L.; Lu, L.; Jiang, S. Testing of middle east respiratory syndrome coronavirus replication inhibitors for the ability to block viral entry. Antimicrob. Agents Chemother. 2015, 59, 742-744. [CrossRef] [PubMed]

27. Zhao, G.; Du, L.; Ma, C.; Li, Y.; Li, L.; Poon, V.K.; Wang, L.; Yu, F.; Zheng, B.J.; Jiang, S.; et al. A safe and convenient pseudovirus-based inhibition assay to detect neutralizing antibodies and screen for viral entry inhibitors against the novel human coronavirus mers-cov. Virol. J. 2013, 10, 266. [CrossRef] [PubMed]

28. Bertram, S.; Glowacka, I.; Blazejewska, P.; Soilleux, E.; Allen, P.; Danisch, S.; Steffen, I.; Choi, S.Y.; Park, Y.; Schneider, H.; et al. Tmprss2 and tmprss4 facilitate trypsin-independent spread of influenza virus in caco-2 cells. J. Virol. 2010, 84, 10016-10025. [CrossRef]

29. Shirogane, Y.; Takeda, M.; Iwasaki, M.; Ishiguro, N.; Takeuchi, H.; Nakatsu, Y.; Tahara, M.; Kikuta, H.; Yanagi, Y. Efficient multiplication of human metapneumovirus in vero cells expressing the transmembrane serine protease tmprss2. J. Virol. 2008, 82, 8942-8946. [CrossRef]

30. Matsuyama, S.; Nagata, N.; Shirato, K.; Kawase, M.; Takeda, M.; Taguchi, F. Efficient activation of the severe acute respiratory syndrome coronavirus spike protein by the transmembrane protease tmprss2. J. Virol. 2010, 84, 12658-12664. [CrossRef]

31. Shirato, K.; Kawase, M.; Matsuyama, S. Middle east respiratory syndrome coronavirus infection mediated by the transmembrane serine protease tmprss2. J. Virol. 2013, 87, 12552-12561. [CrossRef]

32. Zhou, Y.; Vedantham, P.; Lu, K.; Agudelo, J.; Carrion, R., Jr.; Nunneley, J.W.; Barnard, D.; Pohlmann, S.; McKerrow, J.H.; Renslo, A.R.; et al. Protease inhibitors targeting coronavirus and filovirus entry. Antivir. Res. 2015, 116, 76-84. [CrossRef] [PubMed]

33. Engel, J.C.; Doyle, P.S.; Hsieh, I.; McKerrow, J.H. Cysteine protease inhibitors cure an experimental trypanosoma cruzi infection. J. Exp. Med. 1998, 188, 725-734. [CrossRef] [PubMed]

34. De Wilde, A.H.; Jochmans, D.; Posthuma, C.C.; Zevenhoven-Dobbe, J.C.; van Nieuwkoop, S.; Bestebroer, T.M.; van den Hoogen, B.G.; Neyts, J.; Snijder, E.J. Screening of an fda-approved compound library identifies four small-molecule inhibitors of middle east respiratory syndrome coronavirus replication in cell culture. Antimicrob. Agents Chemother. 2014, 58, 4875-4884. [CrossRef] [PubMed]

35. Burkard, C.; Verheije, M.H.; Haagmans, B.L.; van Kuppeveld, F.J.; Rottier, P.J.; Bosch, B.J.; de Haan, C.A. Atp1a1-mediated src signaling inhibits coronavirus entry into host cells. J. Virol. 2015, 89, 4434-4448. [CrossRef] [PubMed]

36. Kim, J.Y.; Kim, Y.I.; Park, S.J.; Kim, I.K.; Choi, Y.K.; Kim, S.H. Safe, high-throughput screening of natural compounds of mers-cov entry inhibitors using a pseudovirus expressing mers-cov spike protein. Int. J. Antimicrob. Agents 2018, 52, 730-732. [CrossRef] [PubMed]

37. Millet, J.K.; Whittaker, G.R. Host cell entry of middle east respiratory syndrome coronavirus after two-step, furin-mediated activation of the spike protein. Proc. Natl. Acad. Sci. USA 2014, 111, 15214-15219. [CrossRef] [PubMed]

38. Chou, C.Y.; Lai, H.Y.; Chen, H.Y.; Cheng, S.C.; Cheng, K.W.; Chou, Y.W. Structural basis for catalysis and ubiquitin recognition by the severe acute respiratory syndrome coronavirus papain-like protease. Acta Crystallogr. Sect. D Biol. Crystallogr. 2014, 70, 572-581. [CrossRef] [PubMed]

39. Han, Y.S.; Chang, G.G.; Juo, C.G.; Lee, H.J.; Yeh, S.H.; Hsu, J.T.; Chen, X. Papain-like protease 2 (plp2) from severe acute respiratory syndrome coronavirus (sars-cov): Expression, purification, characterization, and inhibition. Biochemistry 2005, 44, 10349-10359. [CrossRef]

40. Lee, H.; Lei, H.; Santarsiero, B.D.; Gatuz, J.L.; Cao, S.; Rice, A.J.; Patel, K.; Szypulinski, M.Z.; Ojeda, I.; Ghosh, A.K.; et al. Inhibitor recognition specificity of mers-cov papain-like protease may differ from that of sars-cov. ACS Chem. Biol. 2015, 10, 1456-1465. [CrossRef]

41. Thiel, V.; Ivanov, K.A.; Putics, A.; Hertzig, T.; Schelle, B.; Bayer, S.; Weissbrich, B.; Snijder, E.J.; Rabenau, H.; Doerr, H.W.; et al. Mechanisms and enzymes involved in sars coronavirus genome expression. J. Gen. Virol. 2003, 84, 2305-2315. [CrossRef] [PubMed]

42. Harcourt, B.H.; Jukneliene, D.; Kanjanahaluethai, A.; Bechill, J.; Severson, K.M.; Smith, C.M.; Rota, P.A.; Baker, S.C. Identification of severe acute respiratory syndrome coronavirus replicase products and characterization of papain-like protease activity. J. Virol. 2004, 78, 13600-13612. [CrossRef] [PubMed]

43. Mielech, A.M.; Kilianski, A.; Baez-Santos, Y.M.; Mesecar, A.D.; Baker, S.C. Mers-cov papain-like protease has deisgylating and deubiquitinating activities. Virology 2014, 450-451, 64-70. [CrossRef] [PubMed] 
44. Yang, X.; Chen, X.; Bian, G.; Tu, J.; Xing, Y.; Wang, Y.; Chen, Z. Proteolytic processing, deubiquitinase and interferon antagonist activities of middle east respiratory syndrome coronavirus papain-like protease. J. Gen. Virol. 2014, 95, 614-626. [CrossRef] [PubMed]

45. Galkin, A.; Kulakova, L.; Lim, K.; Chen, C.Z.; Zheng, W.; Turko, I.V.; Herzberg, O. Structural basis for inactivation of giardia lamblia carbamate kinase by disulfiram. J. Boil. Chem. 2014, 289, 10502-10509. [CrossRef] [PubMed]

46. Paranjpe, A.; Zhang, R.; Ali-Osman, F.; Bobustuc, G.C.; Srivenugopal, K.S. Disulfiram is a direct and potent inhibitor of human o6-methylguanine-DNA methyltransferase (mgmt) in brain tumor cells and mouse brain and markedly increases the alkylating DNA damage. Carcinogenesis 2014, 35, 692-702. [CrossRef] [PubMed]

47. Lin, M.H.; Moses, D.C.; Hsieh, C.H.; Cheng, S.C.; Chen, Y.H.; Sun, C.Y.; Chou, C.Y. Disulfiram can inhibit mers and sars coronavirus papain-like proteases via different modes. Antivir. Res 2018, 150, 155-163. [CrossRef]

48. Kumar, V.; Tan, K.P.; Wang, Y.M.; Lin, S.W.; Liang, P.H. Identification, synthesis and evaluation of sars-cov and mers-cov 3c-like protease inhibitors. Bioorg. Med. Chem. 2016, 24, 3035-3042. [CrossRef]

49. Needle, D.; Lountos, G.T.; Waugh, D.S. Structures of the middle east respiratory syndrome coronavirus 3c-like protease reveal insights into substrate specificity. Acta Crystallogr. Sect. D Biol. Crystallogr. 2015, 71, 1102-1111. [CrossRef]

50. Hsu, M.F.; Kuo, C.J.; Chang, K.T.; Chang, H.C.; Chou, C.C.; Ko, T.P.; Shr, H.L.; Chang, G.G.; Wang, A.H.; Liang, P.H. Mechanism of the maturation process of sars-cov 3cl protease. J. Biol. Chem. 2005, 280, 31257-31266. [CrossRef]

51. Hu, T.; Zhang, Y.; Li, L.; Wang, K.; Chen, S.; Chen, J.; Ding, J.; Jiang, H.; Shen, X. Two adjacent mutations on the dimer interface of sars coronavirus $3 c$-like protease cause different conformational changes in crystal structure. Virology 2009, 388, 324-334. [CrossRef]

52. Galasiti Kankanamalage, A.C.; Kim, Y.; Damalanka, V.C.; Rathnayake, A.D.; Fehr, A.R.; Mehzabeen, N.; Battaile, K.P.; Lovell, S.; Lushington, G.H.; Perlman, S.; et al. Structure-guided design of potent and permeable inhibitors of mers coronavirus $3 \mathrm{cl}$ protease that utilize a piperidine moiety as a novel design element. Eur. J. Med. Chem. 2018, 150, 334-346. [CrossRef]

53. Kilianski, A.; Mielech, A.M.; Deng, X.; Baker, S.C. Assessing activity and inhibition of middle east respiratory syndrome coronavirus papain-like and 3c-like proteases using luciferase-based biosensors. J. Virol. 2013, 87, 11955-11962. [CrossRef] [PubMed]

54. Kumar, V.; Shin, J.S.; Shie, J.J.; Ku, K.B.; Kim, C.; Go, Y.Y.; Huang, K.F.; Kim, M.; Liang, P.H. Identification and evaluation of potent middle east respiratory syndrome coronavirus (mers-cov) 3cl(pro) inhibitors. Antivir. Res. 2017, 141, 101-106. [CrossRef] [PubMed]

55. Kim, Y.; Liu, H.; Galasiti Kankanamalage, A.C.; Weerasekara, S.; Hua, D.H.; Groutas, W.C.; Chang, K.O.; Pedersen, N.C. Reversal of the progression of fatal coronavirus infection in cats by a broad-spectrum coronavirus protease inhibitor. PLoS Pathog. 2016, 12, e1005531.

56. Ren, Z.; Yan, L.; Zhang, N.; Guo, Y.; Yang, C.; Lou, Z.; Rao, Z. The newly emerged sars-like coronavirus hcov-emc also has an "achilles' heel": Current effective inhibitor targeting a 3c-like protease. Protein Cell 2013, 4, 248-250. [CrossRef] [PubMed]

57. Muller, C.; Schulte, F.W.; Lange-Grunweller, K.; Obermann, W.; Madhugiri, R.; Pleschka, S.; Ziebuhr, J.; Hartmann, R.K.; Grunweller, A. Broad-spectrum antiviral activity of the eif4a inhibitor silvestrol against corona- and picornaviruses. Antivir. Res. 2018, 150, 123-129. [CrossRef]

58. Agostini, M.L.; Andres, E.L.; Sims, A.C.; Graham, R.L.; Sheahan, T.P.; Lu, X.; Smith, E.C.; Case, J.B.; Feng, J.Y.; Jordan, R.; et al. Coronavirus susceptibility to the antiviral remdesivir (gs-5734) is mediated by the viral polymerase and the proofreading exoribonuclease. mBio 2018, 9, e00221-18. [CrossRef]

59. Cong, Y.; Hart, B.J.; Gross, R.; Zhou, H.; Frieman, M.; Bollinger, L.; Wada, J.; Hensley, L.E.; Jahrling, P.B.; Dyall, J.; et al. Mers-cov pathogenesis and antiviral efficacy of licensed drugs in human monocyte-derived antigen-presenting cells. PLOS ONE 2018, 13, e0194868. [CrossRef]

60. Hart, B.J.; Dyall, J.; Postnikova, E.; Zhou, H.; Kindrachuk, J.; Johnson, R.F.; Olinger, G.G., Jr.; Frieman, M.B.; Holbrook, M.R.; Jahrling, P.B.; et al. Interferon-beta and mycophenolic acid are potent inhibitors of middle east respiratory syndrome coronavirus in cell-based assays. J. Gen. Virol. 2014, 95, 571-577. [CrossRef] 
61. Tao, X.; Mei, F.; Agrawal, A.; Peters, C.J.; Ksiazek, T.G.; Cheng, X.; Tseng, C.T. Blocking of exchange proteins directly activated by camp leads to reduced replication of middle east respiratory syndrome coronavirus. J. Virol. 2014, 88, 3902-3910. [CrossRef] [PubMed]

62. Warren, T.K.; Wells, J.; Panchal, R.G.; Stuthman, K.S.; Garza, N.L.; Van Tongeren, S.A.; Dong, L.; Retterer, C.J.; Eaton, B.P.; Pegoraro, G.; et al. Protection against filovirus diseases by a novel broad-spectrum nucleoside analogue bcx4430. Nature 2014, 508, 402-405. [CrossRef] [PubMed]

63. Peters, H.L.; Jochmans, D.; de Wilde, A.H.; Posthuma, C.C.; Snijder, E.J.; Neyts, J.; Seley-Radtke, K.L. Design, synthesis and evaluation of a series of acyclic fleximer nucleoside analogues with anti-coronavirus activity. Bioorg. Med. Chem. Lett. 2015, 25, 2923-2926. [CrossRef] [PubMed]

64. Shin, J.S.; Jung, E. Saracatinib inhibits middle east respiratory syndrome-coronavirus replication in vitro. Viruses 2018, 10, 283. [CrossRef] [PubMed]

65. Cheung, N.N.; Lai, K.K.; Dai, J.; Kok, K.H.; Chen, H.; Chan, K.H.; Yuen, K.Y.; Kao, R.Y.T. Broad-spectrum inhibition of common respiratory rna viruses by a pyrimidine synthesis inhibitor with involvement of the host antiviral response. J. Gen. Virol. 2017, 98, 946-954. [CrossRef] [PubMed]

66. Lin, S.C.; Ho, C.T.; Chuo, W.H.; Li, S.; Wang, T.T.; Lin, C.C. Effective inhibition of mers-cov infection by resveratrol. BMC Infect. Dis. 2017, 17, 144. [CrossRef] [PubMed]

67. Gupta, P.B.; Onder, T.T.; Jiang, G.; Tao, K.; Kuperwasser, C.; Weinberg, R.A.; Lander, E.S. Identification of selective inhibitors of cancer stem cells by high-throughput screening. Cell 2009, 138, 645-659. [CrossRef]

68. Huczynski, A. Polyether ionophores-promising bioactive molecules for cancer therapy. Bioorg. Med. Chem. Lett. 2012, 22, 7002-7010. [CrossRef]

69. McFadden, G. Gleevec casts a pox on poxviruses. Nat. Med. 2005, 11, 711-712. [CrossRef]

70. Adedeji, A.O.; Singh, K.; Kassim, A.; Coleman, C.M.; Elliott, R.; Weiss, S.R.; Frieman, M.B.; Sarafianos, S.G. Evaluation of ssya10-001 as a replication inhibitor of severe acute respiratory syndrome, mouse hepatitis, and middle east respiratory syndrome coronaviruses. Antimicrob. Agents Chemother. 2014, 58, 4894-4898. [CrossRef]

71. Lundin, A.; Dijkman, R.; Bergstrom, T.; Kann, N.; Adamiak, B.; Hannoun, C.; Kindler, E.; Jonsdottir, H.R.; Muth, D.; Kint, J.; et al. Targeting membrane-bound viral rna synthesis reveals potent inhibition of diverse coronaviruses including the middle east respiratory syndrome virus. PLoS Pathog. 2014, 10, e1004166. [CrossRef] [PubMed]

72. Li, H.S.; Kuok, D.I.T.; Cheung, M.C.; Ng, M.M.T.; Ng, K.C.; Hui, K.P.Y.; Peiris, J.S.M.; Chan, M.C.W.; Nicholls, J.M. Effect of interferon alpha and cyclosporine treatment separately and in combination on middle east respiratory syndrome coronavirus (mers-cov) replication in a human in-vitro and ex-vivo culture model. Antivir. Res. 2018, 155, 89-96. [CrossRef] [PubMed]

73. Clasman, J.R.; Baez-Santos, Y.M.; Mettelman, R.C.; O’Brien, A.; Baker, S.C.; Mesecar, A.D. X-ray structure and enzymatic activity profile of a core papain-like protease of mers coronavirus with utility for structure-based drug design. Sci. Rep. 2017, 7, 40292. [CrossRef]

74. Josset, L.; Menachery, V.D.; Gralinski, L.E.; Agnihothram, S.; Sova, P.; Carter, V.S.; Yount, B.L.; Graham, R.L.; Baric, R.S.; Katze, M.G. Cell host response to infection with novel human coronavirus emc predicts potential antivirals and important differences with sars coronavirus. mBio 2013, 4, e00165-13. [CrossRef] [PubMed]

(C) 2018 by the authors. Licensee MDPI, Basel, Switzerland. This article is an open access article distributed under the terms and conditions of the Creative Commons Attribution (CC BY) license (http://creativecommons.org/licenses/by/4.0/). 